\title{
PAJAK DAN RETRIBUSI DAERAH SEBAGAI SUMBER PENDAPATAN DAERAH (STUDI KASUS DI KABUPATEN/ KOTA DAN PEMERINTAH PROPINSI DI JAWA TIMUR)
}

\author{
Himawan Estu Bagijo \\ Balitbangda Bidang Hukum dan Konstitusi Propinsi Jawa Timur \\ e-mail:@yahoo.com
}

\begin{abstract}
ABSTRAK
Menurut Nr hukum. 28, 2009, setiap pemerintah daerah atau Provience sholud menjadi relay peraturan saja mereka lokal tentang Pajak dan Retribusi. Basis revisi pada dua alasan, pertama, tentang tarif dan waktu; kedua batas untuk mengambil uang dari fiskus. Untuk mencapai target anggaran, pemerintah setempat harus repaidly merevisi semua peraturan daerah. Berdasarkan alasan ini, penelitian ini akan muncul posisi Pajak Daerah dan Retribusi Daerah berurusan dengan Anggaran. Data akan menunjukkan tren pajak dan retribusi, fraom 2007, 2008 dan 2009.
\end{abstract}

Kata Kunci: Pajak, Restribusi, Pemerintahan Daerah

\section{ABSTRACT}

According to law Nr. 28, 2009, every local government or provience sholud be a just they local regulation relay on Tax and Retribusi. The revision base on two reason, first, about tariff and the second, time limits to take some money from fiscus. To reach a target of Budgeting, local government should be repaidly revise all the local regulation. Base on this reason, this research will show up the position of Local Tax and Retribusi dealing with Local Budgeting. The data will show the trend of tax and retribusi, fraom 2007, 2008, and 2009.

Keywords: Tax, Retribusi and local government.

\section{PENDAHULUAN}

Penataan perundang-undangan di bidang keuangan negara dilakukan perubahan dengan ditetapkannya Undang-undang Nomor 28 Tahun 2009 tentang Pajak dan Retribusi Daerah (Lembaran Negara Tahun 2009 No. 130 Tambahan Lembaran Negara Nomor 5049) selanjutnya disebut UU Pajak dan Retibusi Daerah, pada tanggal 15 September Tahun 2009. Jenis pajak dan retribusi daerah yang diatur dalam Undang-Undang Pajak dan Retribusi Daerah yang lama sudah tidak memadai lagi dengan kebutuhan daerah. Pemungutan atas pajak dan retribusi daerah berdasar undang-undang yang lama tidak memadai dalam mendukung peningkatan pendapatan asli daerah (selanjutnya disebut PAD) sehingga daerah selalu menunggu besaran Dana Alokasi Umum (selanjunya disebut DAU) untuk membiayai penyelenggaraan urusan otonomi. Selain itu, daerah banyak merumuskan pajak dan retribusi daerah yang bertentangan dengan prinsip efisiensi, kemudahan investasi, mobilisasi penduduk dan barang antar daerah.

Kerangka teori hukum, menempatkan fungsi Perda tentang Pajak dan Retribusi dalam penyeleng- garaan pemerintahan daerah pada fungsi anggaran, fungsi pengaturan, dan fungsi distribusi (Philipus M. Hadjon, 1995: 28).

Fungsi pertama perda pajak dan retribusi adalah fungsi anggaran yang erat kaitannya dengan fungsi perencanaan. Dengan fungsinya yang demikian, maka pajak dan retribusi mempunyai posisi yang strategis bagi kegiatan pembangunan yang diinginkan di daerah. Kegagalan memenuhi target penerimaan sesuai dengan anggaran, akan berpengaruh terhadap pelaksanaan perencanaan pembangunan yang telah ditetapkan. Muara akhir semuanya ini adalah kegagalan bagi daerah dalam melaksanakan misinya mengembangkan dan meningkatkan pembangunan dalam rangka kesejahteraan rakyat di daerah.

Fungsi kedua perda pajak dan retribusi sehubungan dengan anggaran adalah fungsi pengaturan. Dalam hal ini pemerintah daerah harus menetapkan pengaturan yang jelas tentang jenis maupun besarnya tarif pajak dan retribusi yang dibebankan kepada rakyat. Pengaturan yang dituangkan dalam perda harus dapat menjamin kepastian hukum bagi rakyat di daerah. Makna kepastian hukum dalam 
fungsi pengaturan adalah tidak boleh ada tumpang tindih antara sebuah jenis pajak atau retribusi lainnya yang diikuti dengan kejelasan wewenang pemerintah provinsi dan wewenang kabupaten atau kota.

Fungsi ketiga perda pajak dan retribusi sebagai instrumen anggaran adalah fungsi distribusi. Pemda memainkan peran sebagai fasilitator yang baik dalam distribusi kenyamanan kepada rakyat dengan prinsip "saling dukung" (subsidi silang). Peranan ini tidak dapat lepas dari rasionalitas "prinsip keadilan" dalam proses distribusi penikmatan fasilitas yang dibiayai dari pajak dan retribusi.

Dalam Undang-Undang Pajak dan Retribusi Daerah 2009 telah ditetapkan beberapa jenis pajak daerah yang dapat dipungut oleh daerah. Jenis pajak tersebut antara lain: Pertama, Pajak Hotel dan Restoran; Kedua, Pajak Hiburan; Ketiga, Pajak Reklame; Keempat, Pajak Penerangan Jalan; Kelima, Pajak Pengambilan dan Pengelolaan Bahan Galian Golongan C; Keenam, Pajak Pemanfaatan Air Bawah Tanah dan Air Permukaan.

Selain jenis pajak di atas, pemerintah daerah dilarang melakukan pungutan vide Pasal 2 ayat (3) dan jika potensinya kurang memadai juga tidak perlu dilakukan pemungutan vide Pasal 2 ayat (4). Posisi dilematis terdapat pada konteks ketentuan ini sangat membatasi kreasi daerah yang dalam realitas sering dilakukan, dan di sisi lain hal ini cukup memberikan perlindungan hukum bagi rakyat untuk tidak dipungut berbagai jenis pajak daerah yang tidak mempunyai validitas normatif dan legitimasi dari masyarakat.

Sementara itu, penetapan jenis Retribusi yang berlaku untuk suatu daerah dalam hal-hal tertentu harus sama. Prinsip keadilan harus diberlakukan dalam menetapkan jenis retribusi. Penetapan berlakunya jenis retribusi dipengaruhi oleh dua faktor utama, yaitu faktor sumber daya alam (geografis) dan faktor sumber daya manusia yang akan menjadi objek dan wajib retribusi. Meskipun Undang-Undang Pajak dan Retribusi Daerah telah menetapkan jenis Retribusi, sebagaimana diatur dalam Pasal 108 ayat (1), penerapan di masingmasing daerah akan berbeda-beda sesuai dengan kemampuan yang ada di daerah tersebut. Pendapatan daerah dari sumber retribusi ini bergantung pada seberapa cepat dan tepat aparat pemerintah di daerah menyusun strategi penarikannya.

Objek retribusi adalah berbagai jenis jasa tertentu yang disediakan oleh pemerintah daerah.
Namun, tidak semua jenis jasa yang diberikan oleh pemerintah daerah dapat dipungut retribusi. Hal tersebut tentunya berkaitan dengan pertimbangan sosisal ekonomi, layak atau tidak dijadikan objek retribusi. Jasa tersebut menurut ketentuan Pasal 108 ayat (1) Undang-Undang Pajak dan Retribusi Daerah dibedakan kedalam: Pertama, Jasa Umum; Kedua, Jasa Usaha; Ketiga, Perizinan Tertentu.

Berlakunya undang-undang baru ini tentu menjadi angin segar bagi daerah untuk bersemangat melakukan berbagai penataan kembali produk hukum daerah yang mengatur tentang pajak dan retribusi. Untuk melakukan penataan tersebut tentu harus memperhatikan berbagai hal yang telah diatur dalam berbagai pasal dalam Undang-Undang Nomor 28 Tahun 2009. Untuk hal ini, maka harus diperhatikan ketentan Pasal 179 dan Pasal 180 yang mengatur sebagai berikut: Pada saat Undangundang ini berlaku, Pajak dan Retribusi yang masih terutang berdasarkan Peraturan Daerah mengenai Pajak Provinsi sebagaimana dimaksud dalam Pasal 2 ayat (1) dan jenis pajak kabupaten atau kota sebagaimana dimaksud dalam Pasal 2 ayat (2), dan Peraturan Daerah tentang Retribusi mengenai jenis Retribusi Jasa Umum sebagaimana dimaksud dalam Pasal 110 ayat (1), jenis retribusi Jasa Usaha sebagaimana dimaksud dalam Pasal 127, dan jenis retribusi Perizinan Tertentu sebagaimana dimaksud dalam Pasal 141, sepanjang tidak diatur dalam Peraturan Daerah yang bersangkutan masih dapat ditagih selama jangka waktu 5 (tahun) terhitung sejak saat terutang.

Pasal 180 (1) Peraturan Daerah tentang Pajak Daerah mengenai jenis Pajak provinsi sebagaimana dimaksud dalam Pasal 2 ayat (1) dan jenis Pajak kabupaten/kota sebagaimana dimaksud dalam Pasal 2 ayat (2) masih tetap berlaku untuk jangka waktu 2 (dua) tahun sebelum diberlakukannya Peraturan Daerah yang baru berdasarkan Undang-undang ini; (2) Peraturan Daerah tentang retribusi Daerah jenis Retribusi Jasa Umum sebagaimana dimaksud dalam Pasal 110 ayat (1), jenis Retribusi Jasa Usaha sebagaimana dimaksud dalam Pasal 127, dan jenis Retribusi Perizinan Tertentu sebagaimana dimaksud dalam Pasal 141, masih tetap berlaku untuk jangka waktu 2 (dua) tahun sebelum diberlakukannya Peraturan Daerah yang baru berdasarkan Undangundang ini.

Mencermati isi ketentuan peralihan dalam Undang-Undang Nomor 28 Tahun 2009 tersebut, maka tidak dapat ditawar lagi bahwa jangka waktu 
berlakunya perda pajak dan retribusi adalah 2 (dua) tahun. Jadi siap atau tidak, pemerintah daerah harus menghentikan semua jenis pemungutan pajak dan retribusi yang tidak sesuai dengan ketentuan di atas. Permasalahannya, apakah penghentian pemungutan tersebut menunggu perda yang baru?

Berdasar uraian tersebut di atas, maka permasalahan kajian ini dirumuskan sebagai berikut: "Bagaimanakah potret potensi Pajak dan Retribusi Daerah terhadap kemampuan keuangan daerah?"

\section{PAJAK DAN RETRIBUSI DAERAH}

Pajak dan Retribusi daerah merupakan bagian pendapat yang strategis bagi daerah untuk biaya penyelenggaraan pemerintahan. Dalam upaya mengelola urusan pemerintahan daerah yang lahir sebagai konsekwensi otonomi, daerah harus mampu mengumpulkan uang sebagai instrumen pembiayaan. Berdasarkan Undang-Undang Pemerintah Daerah, diatur pembagian urusan yang sifatnya wajib dan urusan yang sifatnya pilihan yang harus diselenggarakan oleh pemerintah daerah. Secara skematis pola pembagian urusan tersebut adalah sebagai berikut: tersebut, maka pemerintah daerah diberi wewenang melakukan pemungutan yang berupa pajak dan atau retribusi daerah sebagaimana diatur dalam UndangUndang Nomor 33 Tahun 2004. Dalam UndangUndang Nomor 32 Tahun 2004, juga dinyatakan secara tegas dalam ketentuan Pasal 157.

Sumber pendapatan daerah terdiri atas: Pertama, pendapatan asli daerah yang selanjutnya disebut PAD, yaitu: (1) hasil pajak daerah; (2) hasil retribusi daerah; (3) hasil pengelolaan kekayaan daerah yang dipisahkan; dan (4) lain-lain PAD yang sah; Kedua, dana perimbangan; dan Ketiga, lain-lain pendapatan daerah yang sah.

Berdasar ketentuan Pasal 157 Undang-Undang Nomor 32 Tahun 2004 ini, selanjutnya pemerintah daerah melakukan upaya pemungutan pajak dan retribusi daerah. Agar pemungutan itu tidak menimbulkan permasalahan bagi rakyat di daerah, maka diatur dalam Undang-undang tentang pajak dan retribusi daerah. Saat ini, undang-undang yang diberlakukan adalah Undang-Undang Nomor 28 Tahun 2009 tentang Pajak dan Retribusi Daerah.

Hasil pungutan pajak dan retribusi daerah menjadi sumber utama pendapatan asli daerah.

Gambar 1

Skema Pembagian urusan Pemerintah berdasar UU Nomor 32 Tahun 2004

ANATOMI URUSAN PEMERINTAHAN

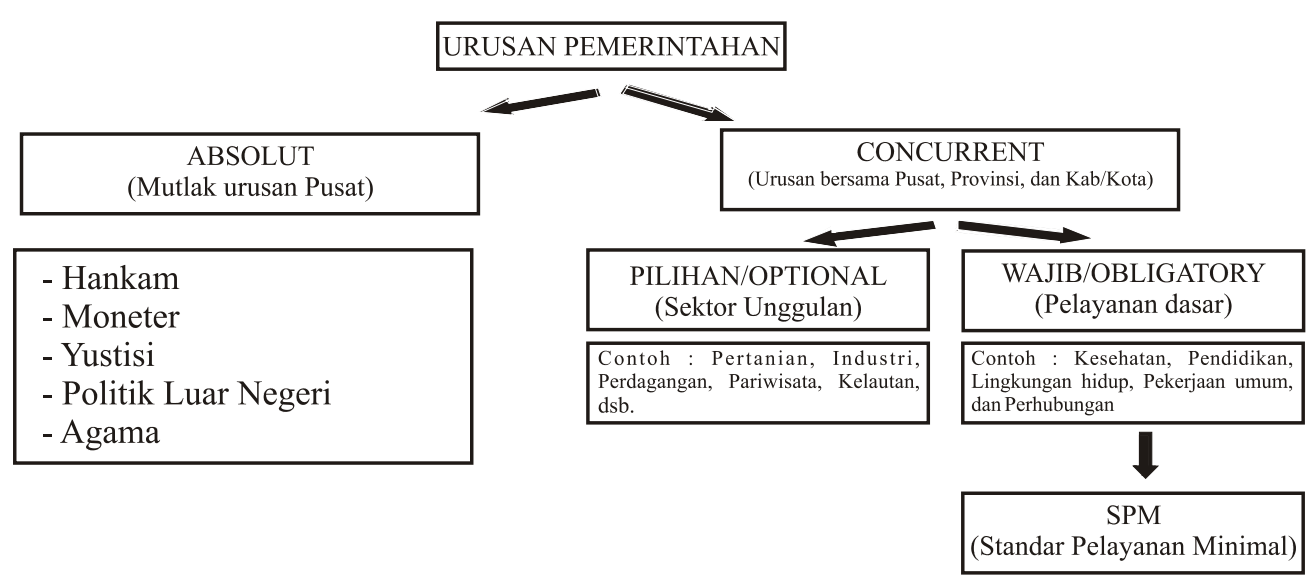

Tata kelola kepemerintahan di daerah harus diarahkan untuk menyelenggarakan urusan yang menjadikewenangandaerah. Urusan penyelengaraan daerah terbagi ke dalam urusan wajib yang berupa pelayanan dasar dan urusan pilihan. Pengaturan lebih rinci tentang pelaksanaan urusan daerah ini ditetapkan dalam Peraturan Pemerintah Nomor 37 Tahun 2008 tentang Penyelenggaraan Urusan Provinsi dan Urusan Kabupaten atau Kota.

Untuk mampu membiayai pelaksanaan urusan
Selanjutnya PAD menjadi indikator keberhasilan kinerja pemerintahan daerah yang pada akhirnya akan menjadi kekuatan utama dalam mendukung APBD (khususnya Pendapatan Daerah).

\section{Pertumbuhan PAD terhadap Pendapatan Daerah di Kabupaten Lamongan}

Kondisi Kabupaten Lamongan saat ini dikenal sebagai Kabupaten yang sukses dalam meningkatkan pertumbuhan ekonomi masyarakatnya. Perkem- 
bangan pendapatan asli daerahnya pun berbanding lurus dengan peningkatan besaran APBDnya. Hal ini menunjukkan bahwa Pemerintah Kabupaten Lamongan bekerja keras untuk dari tahun ke tahun meningkatkan jumlah penerimaan dari sektor pajak dan retrbusi. Dalam Tabel 1. Berikut dapat dilihat perkembangan pendapatan dari sektor PAD tahun 2007, 2008, dan 2009 dibandingkan dengan pendapatan daerah pada tahun yang sama. Peningkatan pendapatan daerah pasti selalu terjadi di daerah, tetapi tidak selalu hal itu dibarengi dengan kenaikan pendapatan asli daerah. Oleh sebab itu, layak jika Lamongan dikategorikan sebagai Kabupaten yang bertumbuh pesat dan berhasil dalam pelaksanaan otonomi daerah.
Perkotaan dan Pedesaan. Sementara, jenis pajak daerah yang kurang potensiil adalah: Pajak Parkir dan Pajak Sarang Burung Walet.

Terhadap pengelolaan pajak daerah, pertumbuhan di Kabupaten lamongan tidak terlalu menggembirakan jika dilihat dalam prosentase. Secara keseluruhan hasil pengumpulan dari pajak daerah terus meningkat berkisar $10-14 \%$ per tahun dari tahun anggaran berjalan (lihat tabel 2.) Namun jika dibaca perbandingannya dengan APBD, maka terjadi penurunan prosentase. Mengapa hal ini bisa terjadi? Penerimaan dari sektor pajak daerah tidak mudah dikembangkan karena 2 faktor, pertama, jenis pajak daerah tidak dapat dikembangkan dengan mudah, mengingat hal ini berkaitan dengan

Tabel 1

Prosentase Penerimaan PAD terhadap Pendapatan Daerah Kab. Lamongan Tahun Anggaran 2007, 2008, 2009

\begin{tabular}{lccc}
\hline & Tahun 2007 & Tahun 2008 & Tahun 2009 \\
\hline Pendapatan daerah & $661.759 .337,198$ & $756.709 .359,748$ & $869.777 .965,365$ \\
PAD & $43.058 .501 .192,83$ & $55.639 .143 .645,00$ & $66.608 .873 .942,51$ \\
Prosentase & $6,5 \%$ & $7,4 \%$ & $7,7 \%$ \\
\hline
\end{tabular}

\section{Pertumbuhan Pajak Daerah}

Di Kabupaten Lamongan, terdapat berbagai jenis pajak daerah yang sebelum berlakunya UndangUndang Nomor 28 Tahun 2009. Dari sejumlah jenis pajak daerah yang dipungut, yang merupakan jenis pajak potensiil adalah: Pajak Penerangan Jalan dan Pajak Reklame (pajak daerah). Sementara itu, Lamongan juga memperoleh tambahan penghasilan dari tugas memungut Pajak Bumi dan Bangunan obyek pungutan yang sifatnya given. Kedua, jumlah wajib pajak lambat bertumbuh berikut besaran pungutan yang juga bersifat tetap.

Jika dinilai dari kenaikan penerimaan, apa yang terjadi di Lamongan masuk dalam kategori sangat baik, karena terdapat pertumbuhan yang sangat signifikan atas penerimaan dari sektor pajak daerah.

\section{Grafik 1}

Perbandingan Penerimaan PAD terhadap Pendapatan Daerah Kab. Lamongan Tahun 2007, 2008, 2009

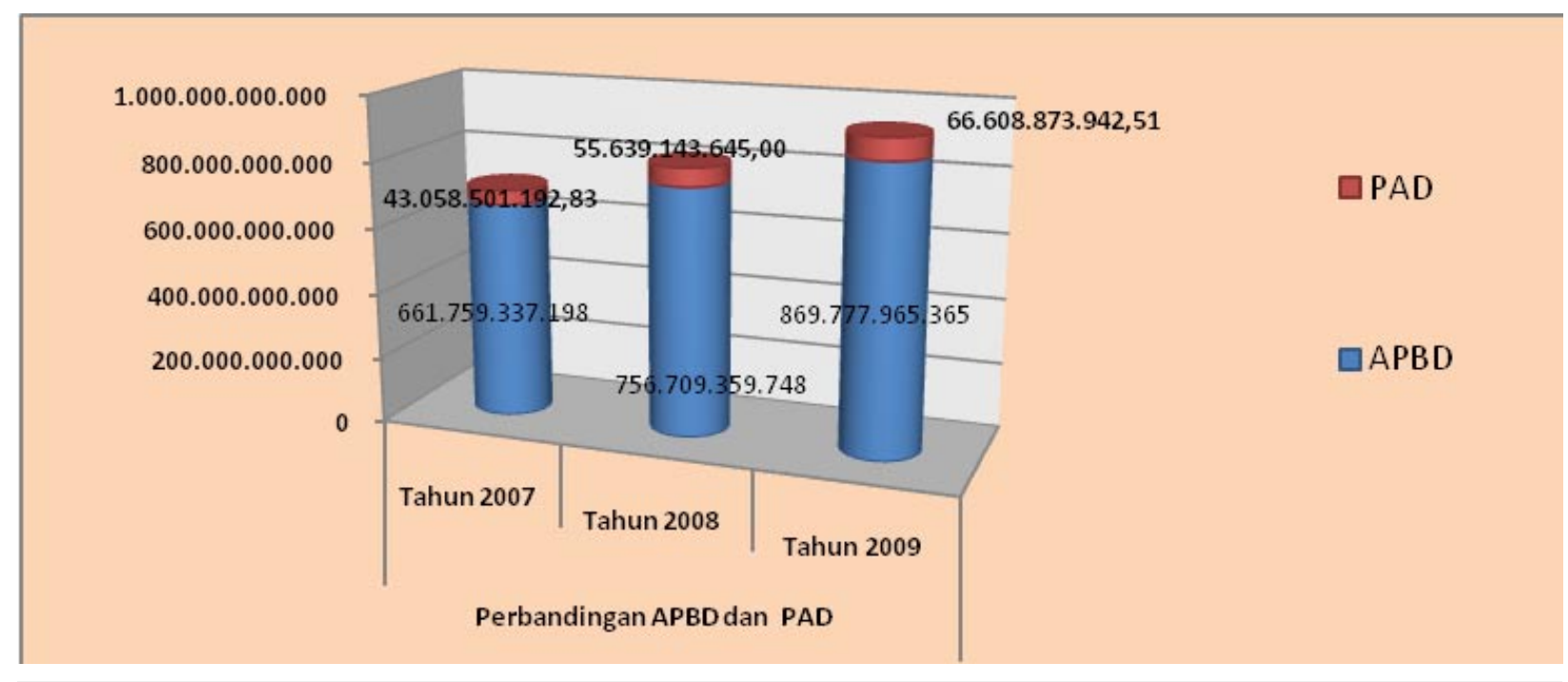


Tabel 2

Prosentase Penerimaan PAD terhadap Pendapatan Daerah Kab. Lamongan Tahun Anggaran 2007, 2008, 2009

\begin{tabular}{lccc}
\hline & Tahun 2007 & Tahun 2008 & Tahun 2009 \\
\hline PAD & $43.058 .501 .192,83$ & $55.639 .143 .645,00$ & $66.608 .873 .942,51$ \\
Pajak Daerah & $10.909 .571 .668,90$ & $11.993 .879 .168,00$ & 14.271 .468 .396 .00 \\
Prosentase terhadap Pendapatan & $1,6 \%$ & $1,6 \%$ & $1,6 \%$ \\
$\begin{array}{l}\text { Daerah } \\
\text { Prosentase terhadap PAD }\end{array}$ & $25,3 \%$ & $21,6 \%$ & $21,4 \%$ \\
\hline
\end{tabular}

Grafik 2.

Perbandingan Penerimaan Pajak Daerah terhadap Pendapatan Daerah Kab. Lamongan Tahun Anggaran 2007, 2008, 2009

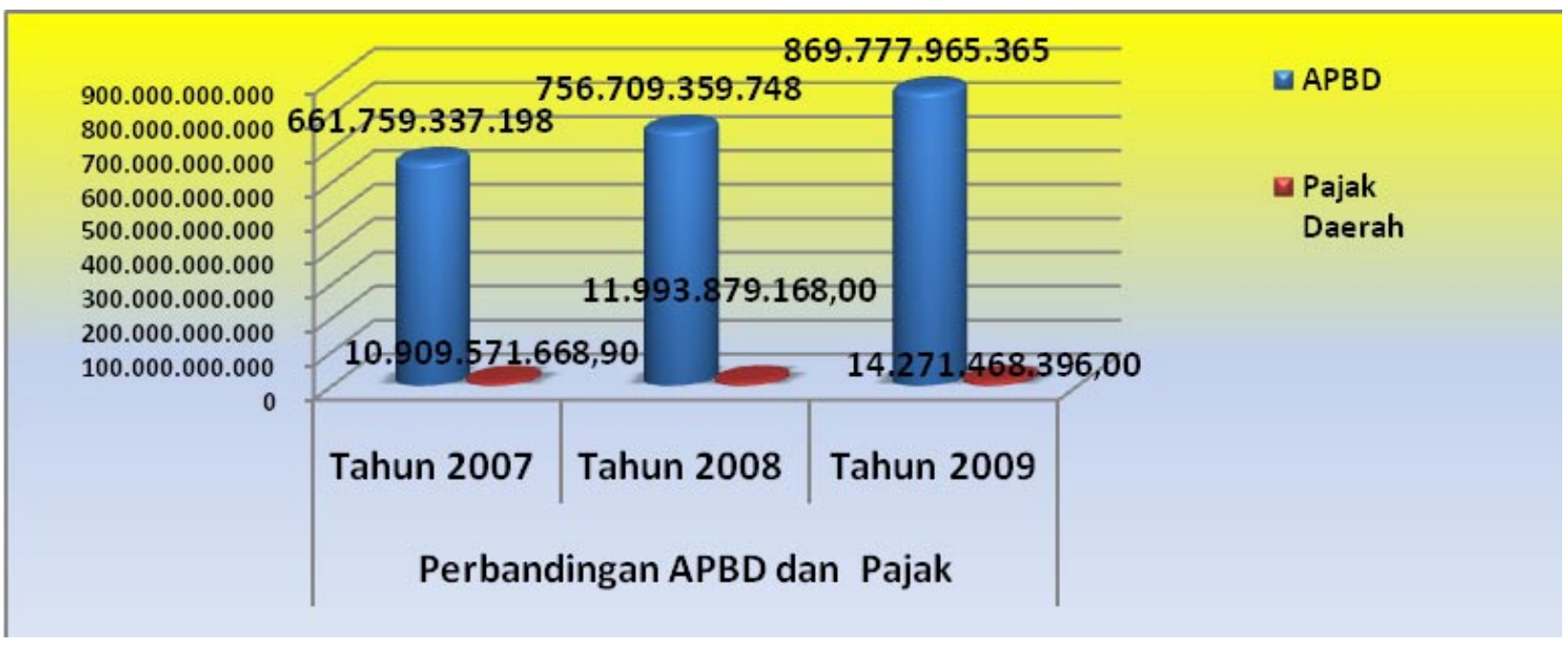

\section{Pertumbuhan Retribusi Daerah}

Perihal retribusi daerah Kabupaten Lamongan melakukan pemungutan yang didasarkan pada berbagi jenis retribusi. Jenis retribusi yang dipungut terbagi atas 3 (tiga) kelompok, yaitu: Retribusi Jasa Umum, Retribusi Jasa Usaha dan Retribusi Perijinan Tertentu.

Terhadap jenis, jenis retribusi yang dipungut di Lamongan, terdapat tiga jenis yang sangat potensiil yaitu: Retribusi Ijin Mendirikan Bangunan, Retri- busi Pelayanan Kesehatan, dan Retribusi Pelayanan Parkir Tepi Jalan. Sementara itu, retribusi yang kurang potensiil adalah: Retribusi Ijin Bidang Pariwisata, Retribusi Ijin Pengambilan Air Bawah Tanah, dan Retribusi Tanda Daftar Gudang.

Jika dilihat pada tabel 3, maka nampak jelas pertumbuhan penerimaan retribusi di Kabupaten Lamongan betumbuh pesat pada tahun 2009. Dibandingkan dengan penerimaan pada tahun 2008, maka terdapat kenaikan hampir $20 \%$ dari perolehan

Tabel 3

Prosentase Penerimaan Retribusi Daerah terhadap PAD dan Pendapatan Daerah Kab. Lamongan Tahun Anggaran 2007, 2008, 2009

\begin{tabular}{lccc}
\hline & Tahun 2007 & Tahun 2008 & Tahun 2009 \\
\hline PAD & $43.058 .501 .192,83$ & $55.639 .143 .645,00$ & $66.608 .873 .942,51$ \\
Pajak Daerah & $18.080 .077 .425,00$ & $19.618 .544 .117,00$ & 24.300 .382 .597 .00 \\
Prosentase terhadap Pendapatan & $2,7 \%$ & $2,6 \%$ & $2,8 \%$ \\
Daerah & & & \\
Prosentase terhadap PAD & $42,0 \%$ & $35,3 \%$ & $36,5 \%$ \\
\hline
\end{tabular}


Grafik 3

Perbandingan Penerimaan Retribusi Daerah terhadap Pendapatan Daerah Kab. Lamongan Tahun Anggaran 2007, 2008, 2009

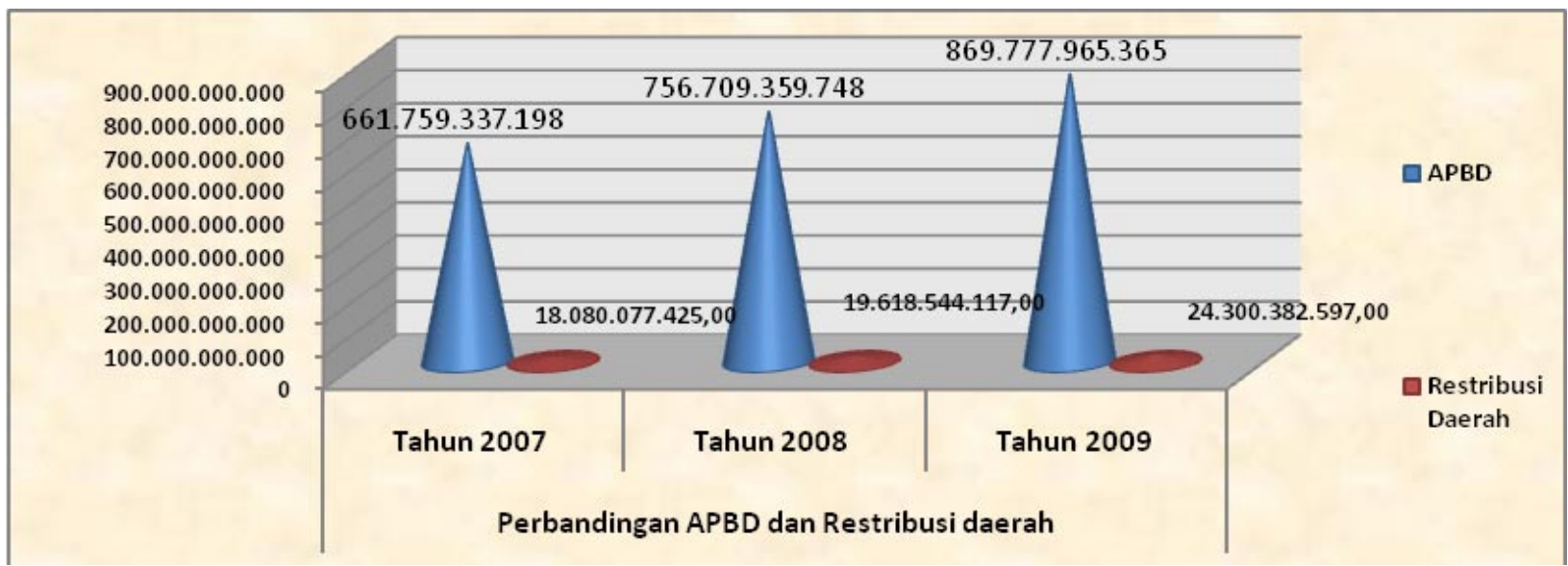

tahun 2008 di tahun 2009. Hal ini berbeda dengan penerimaan di tahun 2008 dibandingkan dengan tahun 2007, kenaikin sekitar 10-14\%.

Secara keseluruhan penerimaan Retribusi di Kabupaten Lamongan di Tahun 2007, 2008 dan 2009 mengalami kenaikan. Namun demikian, perolehan dari retribusi ini prosentasenya menurun jika dibandingkan dengan pertumbuhan APBD Lamongan di tahun 2007, 2008 dan 2009, Namun demikian secara keseluruhan pengelolaan retribusi masih tetap meningkat dengan baik (lihat tabel 3)

Secara keseluruhan, pertumbuhan penerimaan Kabupaten Lamongan baik dari pajak maupun retribusi daerah dapat dikatakan sangat baik. Hal ini menandakan adanya pertumbuhan perekonomian yang sangat maju. Oleh sebab itu, sudah selayaknya jika Kabupaten Lamongan segera melakukan penyesuaian pengaturan perda pajak dan retribusinya sesuai dengan UU Nomor 28 Tahun 2009.

\section{Pertumbuhan PAD terhadap Pendapatan Daerah Kabupaten Pasuruan}

Kabupaten Pasuruan, termasuk dalam kelompok kabupaten besar, dengan jumlah penduduk banyak dan potensi daerahnya yang beragam. Pasuruan sebelah utara berbatasan dengan wilayah pantai dengan sumberdaya lautnya. Sebelah barat, berbatasan dengan Kabupaten Sidoarjo dengan memliki kawasan Industri yang sangat luas yaitu Pasuruan Industrial Estate Rembang (PIER). Sementara itu, di wilayah selatan dan tenggara kaya dengan wilayah wisata alam.

Pertumbuhan penerimaan daerah yang dikumpulkan dalam bentuk PAD, dari tahun ke tahun mengalami peningkatan, meskipun jika, dilakukan analisis mendalam terjadi penurunan prosentase. Hal ini dapat dilihat pada PAD tahun 2008 dibandingkan dengan APBD. Jika pada thaun 2007 dapat mencatatkan besaran $8 \%$ ternyata pada tahun 2008 turun menjadi 7\% dari total APBD. Hal ini terjadi berkaitan dengan proses PILKADA tahun 2009 dan akhir masa jabatan Bupati di 2008.

Pada grafik 4 berikut dapat dibaca perbandingan pertumbuhan PAD kabupaten Pasuruan terhadap APBD. Secara grafik nampak bahwa tidak ada kemajuan yang signifikan dari tahun ke tahun dibandingkan dengan APBDnya. Pemerintah Daerah sengaja membuat pertumbuhan yang konstan sekitar 8-9 persen dalam satu tahun anggaran.

Tabel 4

Perbandingan Peneriomaan PAD terhadap Pendapatan Daerah Kabupaten Pasuruan Tahun Anggaran 2007, 2008, 2009

\begin{tabular}{lccc}
\hline & Tahun 2007 & Tahun 2008 & Tahun 2009 \\
\hline Pendapatan Daerah & 750.969 .017 .650 & 875.297 .821 .070 & 889.771 .630 .830 \\
Besaran PAD & 60.010 .543 .432 & 65.647 .336 .588 & 71.181 .739 .381 \\
Prosentase & $8,0 \%$ & $7,5 \%$ & $8,0 \%$ \\
\hline
\end{tabular}


Grafik 4

Pertumbuhan PAD terhadap Pendapatan Daerah

Kabupaten Pasuruan Tahun Anggaran 2007, 2008, 2009

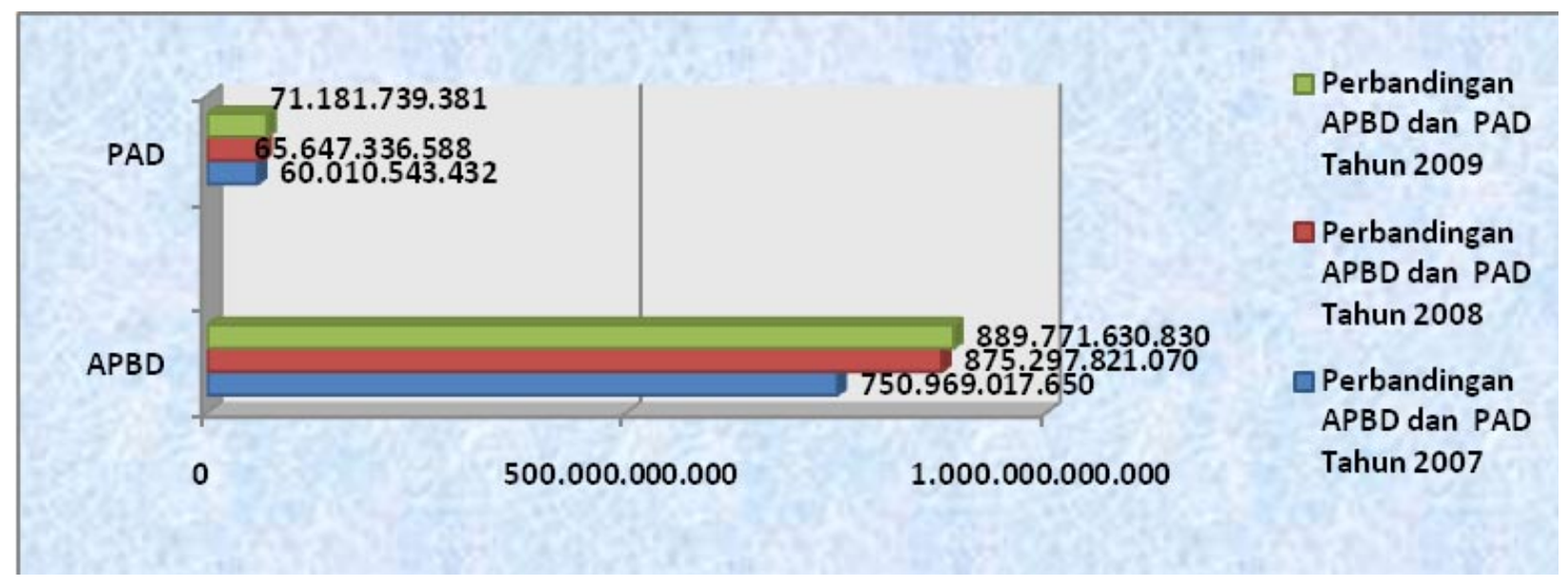

Tabel 5

Prosentase Penerimaan Pajak Daerah terhadap PAD dan Pendapatan Daerah Kabupaten Pasuruan Tahun Anggaran 2007, 2008, 2009

\begin{tabular}{lccc}
\hline & Tahun 2007 & Tahun 2008 & Tahun 2009 \\
\hline Besaran Pajak Daerah & $38.914 .000,000$ & 40.439 .000 .000 & 40.989 .000 .000 \\
Prosentase terhadap Pendapatan & $5,2 \%$ & $4,6 \%$ & $4,6 \%$ \\
Daerah & & & $51,6 \%$ \\
Prosentase terhadap PAD & $64,8 \%$ & $57,6 \%$ \\
\hline
\end{tabular}

\section{Pertumbuhan Pajak Daerah}

Jenis pajak daerah yang diberlakukan di Kabupaten Pasuruan, jumlahnya sama dengan yang di atur dalam Undang-Undang Nomor 18 Tahun 1997 sebagai-mana diubah dengan Undang-Undang Nomor 34 Tahun 2000. Jenis Pajak Daerah yang masuk kategori potensiil adalah Pajak Penerangan Jalan, Pajak Restoran dan Pajak Hotel. Sementara itu, jenis pajak yang kurang potensial adalah: Pajak Parkir, Pajak Sarang Burung Walet, dan Pajak Pengambilan Bahan Galian Golongan C.

Pada Tabel 5. dapat dibaca perkembangan penerimaan dari sektor pajak yang sangat besar. Hal ini menandakan pertumbuhan ekonomi dari sektor investasi berjalan baik dan lancar. Meskipun secara berurutan terdapat penurunan prosentase penerimaan dari tahun 2007 hingga 2009. Hal ini sangat beralasan karena subyek pajak dapat berpindah-pindah domisi dan kegiatannya. Dalam kaitannya dengan ke-mampuan daerah membiayai diri sendiri, kemampuan Kabupaten Pasuruan dapat dinyatakan sangat potensiil. Hal ini danpak dari prosentase penerimaan pajak daerah terhadap PAD yang mencapai besaran lebih dari $50 \%$.
Disisi lain. Tingginya penerimaan pajak daerah ini mengindikasikan besarnya pertumbuhan investasi yang didalamnya disertai dengan penyerapan tenaga kerja.

Pada grafik 5 berikut, dapat dibaca perbandingan pertumbuhan pajak daerah yang semakin menurun dari tahun ke tahun terhadap APBD. Kenaikan nominal pada tahun 2008 justru turun dalam prosentase perbandingan dengan APBD dan PAD. Hal ini menunjukkan turunnya pertumbuahan ekonomi Kabupaten Pasuruan pada tahun 2008. Penyebab utamnya adalah pemilihan kepada daerah yang berpengaruh besar terhadap kinerja satuan kerja perangkat daerah.

Grafik pertumbuhan perolehan retribusi daerah dari tahun 2007 hingga 2009 menunjukkan pertumbuhan yang konstan berkisar 15$18 \%$. Analisis terhadap data ini adalah antara perencanaan dan capaian sudah sesuai atau capaian yang direncanakan sudah diprediksi dapat dicapai. Dengan demikian keberhasilan penyelenggara pemerintahan belum menunjukkan kinerjanya yang maksimal. Hal ini memang sering terjadi dalam perumusan APBD dan capaian anggaran. 
Grafik 5

Perbandingan Penerimaan Pajak Daerah terhadap Pendapatan Daerah Kabupaten Pasuruan Tahun Anggaran 2007, 2008, 2009

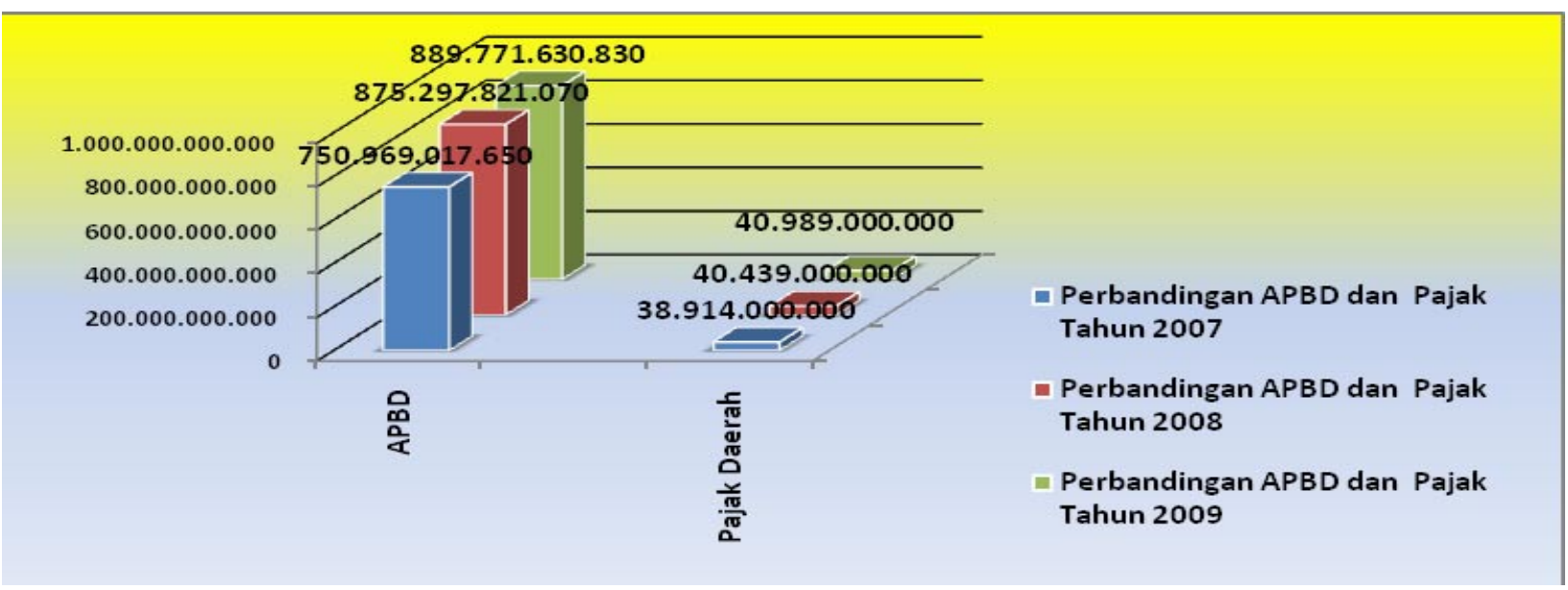

Tabel 6

Prosentase Penerimaan Retribusi terhadap PAD dan Pendapatan Daerah

Kabupaten Pasuruan Tahun Anggaran 2007, 2008, 2009

\begin{tabular}{lccc}
\hline & Tahun 2007 & Tahun 2008 & Tahun 2009 \\
\hline Besaran Retribusi & 14.633 .089 .860 & 17.011 .664 .450 & 21.998 .949 .950 \\
Prosentase terhadap Pendapatan & $2,0 \%$ & $2,0 \%$ & $2,5 \%$ \\
Daerah & & & $30,9 \%$ \\
Prosentase terhadap PAD & $24,4 \%$ & $25,9 \%$ & \\
\hline
\end{tabular}

Grafik 6

Perbandingan Penerimaan Retribusi terhadap PAD dan Pendapatan Daerah Kabupaten Pasuruan Tahun Anggaran 2007, 2008, 2009

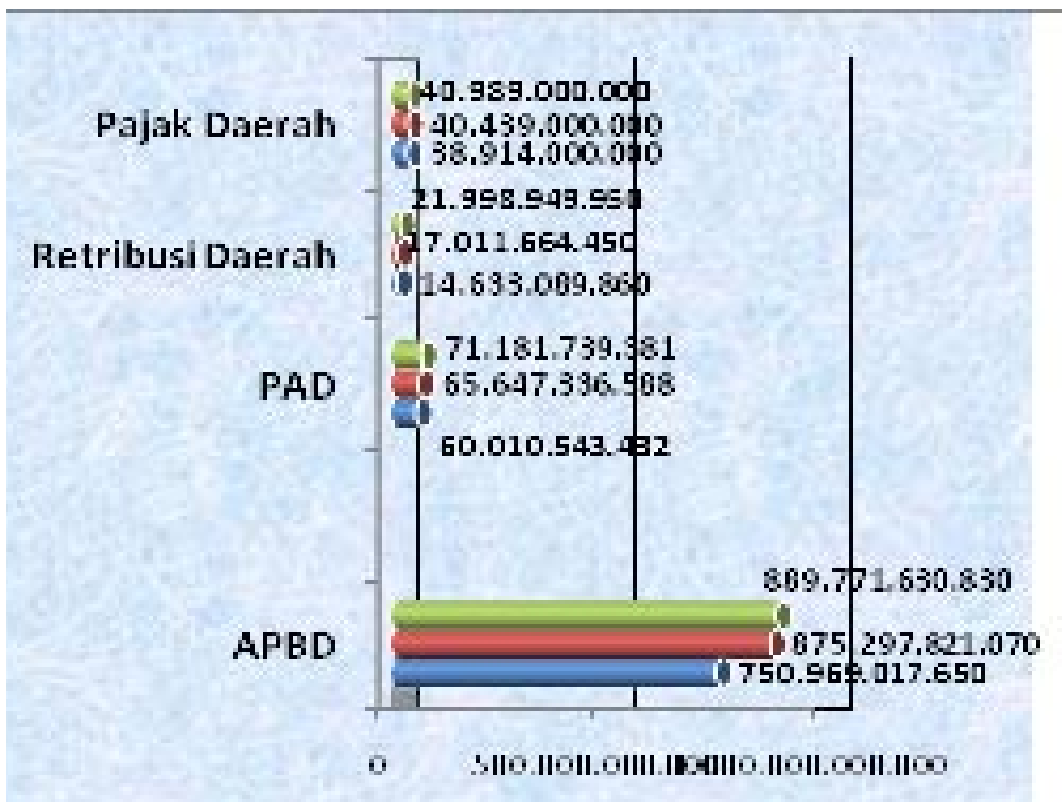

- Perbandingan APBD,PAD, Pajak Daerah, dan Restribusi Tahun 2009

Perbandingan APBD,PAD, Pajak Deerah, dan Restribusi Tahun 2008

Perbandingan APBD,PAD. Pajak Daerah, dan Restribusi Tahun 2007 
Tabel 7

Prosentase Penerimaan Retribusi terhadap PAD dan Pendapatan Daerah

Kabupaten Pasuruan Tahun Anggaran 2007, 2008, 2009

\begin{tabular}{lccc}
\hline & Tahun 2007 & Tahun 2008 & Tahun 2009 \\
\hline Penerimaan Daerah & 336.668 .475 .000 & 372.780 .514 .506 & 378.537 .220 .000 \\
PAD & 22.444 .565 .605 & 27.014 .134 .401 & 43.871 .880 .253 \\
Prosentase & $6,8 \%$ & $7,2 \%$ & $10,5 \%$ \\
\hline
\end{tabular}

Grafik 7

Perbandingan Penerimaan PAD terhadap Pendapatan Daerah

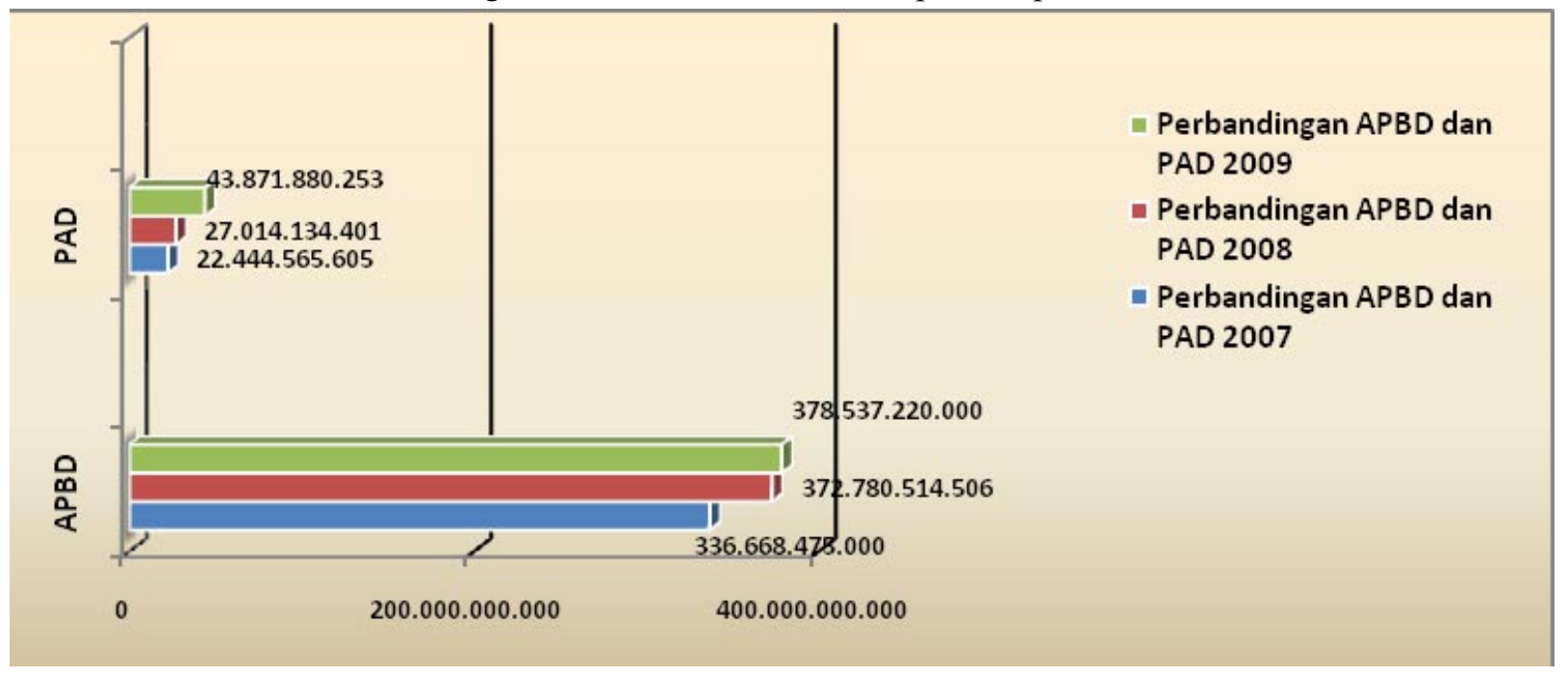

Dalam perencanaan pendapatan, target capaian sering dibuat lebih rendah (markdown) dari potensi sebenarnya. Hal ini akan mempermudah bagi pemerintah untuk memenuhi target. Lebih dari itu, capaian bisa melampaui terget yang dan bisa dinyatakan berprestasi.

\section{Pertumbuhan PAD terhadap Pendapatan Daerah Kota Madiun}

Dari segi luas wilayah, Kota Madiun masuk pada kelompok sedang, didukung dengan 3 kecamatan (layak untuk menjadi 5 kecamatan). Posisi Kota Madiun berada ditengah berbagai kabupaten lain di wilayah barat Jawa Timur. Kota Madiun menjadi daerah penghubung Kab.Ponorogo, Kab. Ngawi, Kab. Magetan dan Kab. Madiun sendiri yang menjadi daerah induknya.

\section{Pertumbuhan Pajak Daerah}

Dalam konteks perkembangan daerah, Pajak Daerah menjadi indikator keberhasilan investasi di daerah tersebut. Selain itu, pajak daerah juga menjadi ukuran kinerja pemerintahan dalam aspek pengembangan wilayah memfasilitasi masuknya investor di dalam wilyah tersebut. Jenis Pajak yang poetensiil di Kota Madiun, adalah: Pajak Hotel, Pajak Hiburan dan Pajak Reklame. Sedangkan yang masuk kategori kurang potensiil adalah: Pajak Minerl Bukan Logam dan Batuan, Pajak Air Tanah, dan Pajak Sarang Burung Walet.

Pada tabel 8 terpapar penerimaan Kota Madiun dari sektor pajak daerah terus menurun sejak Tahun 2007 hingga 2009. Oleh sebab itu, perlu dilakukan pengelolaan aset daerah untuk menarik investor lebih banyak ke Kota Madiun. Untuk itu, dibutuhkan proses pembaharuan pelayanan publik yang mempermudah proses perijinan investasi guna menumbuhkan pungutan di sektor pajak daerah.

Dalam konteks pertumbuhan daerah, maka Kota Madiun termasuk pada kota yang sangat kecil, hal ini mengingat juga jumlah kecamatan dan penduduknya sedikit. Oleh sebab itu, pertumbuhan Kota Madiun perlu menambah wilayah kerja dan jumlah penduduk. Dengan demikian akan menambah jumlah penghasilan dari unsur pajak daerah. 
Tabel 8

Prosentase Penerimaan Pajak Daerah terhadap PAD dan Pendapatan Daerah Kota Madiun Tahun Anggaran 2007, 2008, 2009

\begin{tabular}{lccc}
\hline & Tahun 2007 & Tahun 2008 & Tahun 2009 \\
\hline PAD & 22.444 .565 .605 & 27.014 .134 .401 & 43.871 .880 .253 \\
Pajak & 7.864 .616 .849 & 8.597 .497 .646 & 9.427 .601 .807 \\
Prosentase atas Penerimaan & $2,3 \%$ & $2,3 \%$ & $2,2 \%$ \\
$\begin{array}{l}\text { Daerah } \\
\text { Prosentase atas PAD }\end{array}$ & $35,0 \%$ & $31,8 \%$ & $21,5 \%$ \\
\hline
\end{tabular}

Grafik 8

Perbandingan Penerimaan Pajak Daerah terhadap Pendapatan Daerah

Kota Madiun Tahun Anggaran 2007, 2008, 2009

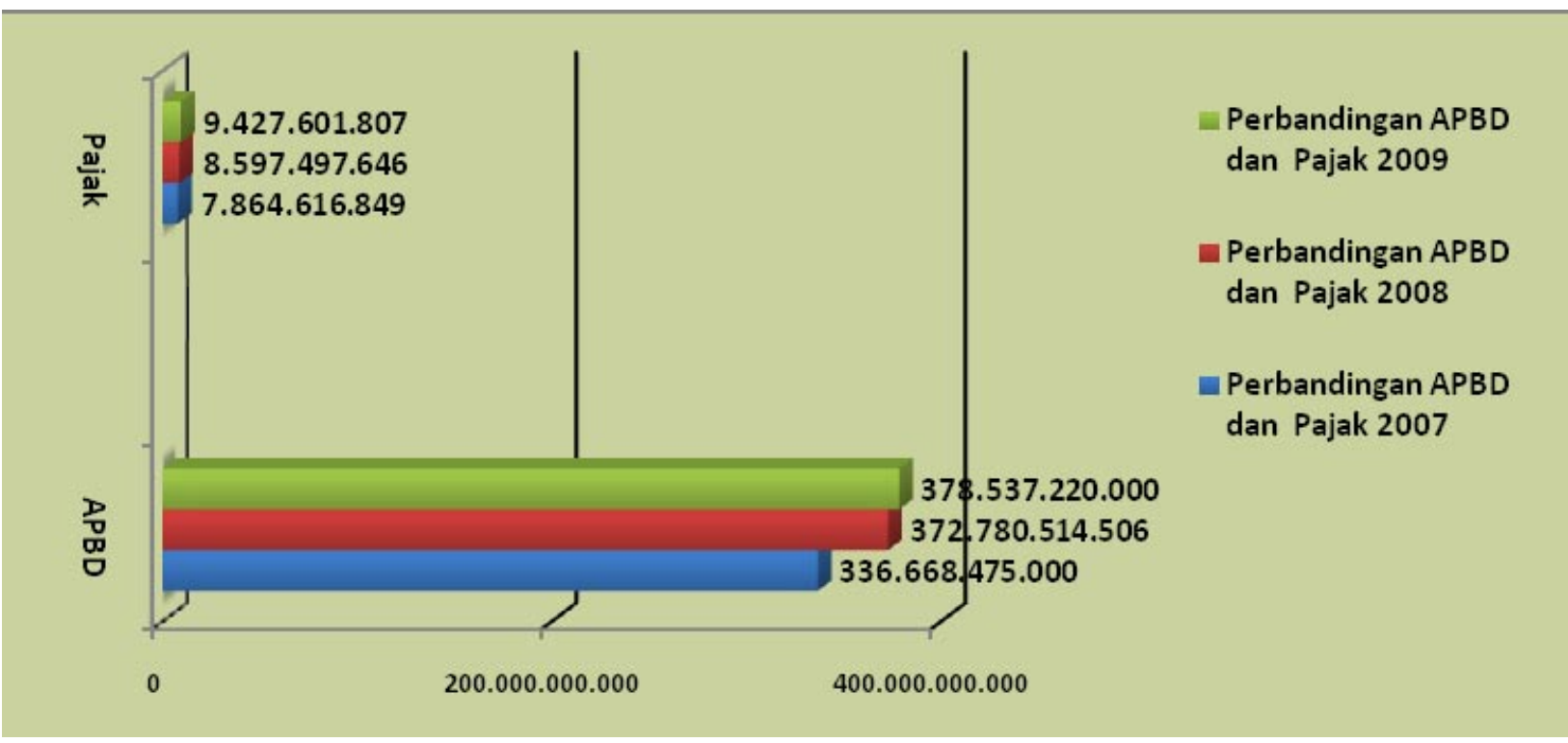

\section{Pertumbuhan Retribusi Daerah}

Sebagai kota pusat pertumbuhan di wilayah barat untuk Provinsi Jawa Timur, Kota Madiun mengembangkan berbagai jenis retribusi yang diharapkan dapat mendulang rupiah untuk meningkatkan PAD.

Mencermati banyaknya jenis retribusi yang dipungut di Kota Madiun, memperlihatkan banyaknya jenis aktivitas masyarakat dalam lalu lintas perekonomian. Dalam satu sisi, pertumbuhan kota menuju kota jasa dan perdagangan menunjukkan kemajuan yang signifikan. Oleh sebab itu, suasana yang nyaman untuk aktivitas dan pola pelayanan birokrasi yang baik, akan menjadi faktor peningkatan petumbuhan ekonomi dan pada akhirnya mampu meningkatkan perolehan pendapatan kota Madiun dari sektor retribusi. Terdapat tiga jenis Retribusi yang potensiil di kota Madiun, yaitu: Retribusi Pemakaian Kekayaan
Daerah, Retribusi Parkir di tepi Jalan, dan Retribusi Izin Mendirikan Bangunan. Sedang yang masuk kategori kurang potensiil adalah: Retribusi Pelayanan Pelabuhan, Retribusi Penyeberangan di Air. dan Retribusi Izin Usaha Perikanan.

Seperti diskripsi dalam Tabel 9, nampak bahwa mesikipun perbandingan prosentase penerimaan dari tahun ke tahun menurun terhadap APBD, namun secara nominal, perolehan retribusi meningkat. Kesimpulannya Kota Madiun terus bertumbuh dalam sektor perekonomian dan tetap layak disebut sebagai kota pertumbuhan di wilayah barat Jawa Timur.

\section{Pertumbuhan PAD terhadap Pendapatan Daerah Kota Mojokerto}

Kota Mojokerto masuk dalam kotegori kota kecil, yang hanya terdiri atas 2 kecamatan, yaitu Kecamatan Prajurit Kulon dan Kecamatan 
Tabel 9

Prosentase Penerimaan Retribusi terhadap PAD dan Pendapatan Daerah Kota Madiun Tahun Anggaran 2007, 2008, 2009

\begin{tabular}{lccc}
\hline & Tahun 2007 & Tahun 2008 & Tahun 2009 \\
\hline PAD & 22.444 .565 .605 & 27.014 .134 .401 & 43.871 .880 .253 \\
Retribusi & 9.389 .439 .796 & 11.626 .157 .683 & 13.653 .458 .797 \\
$\begin{array}{l}\text { Prosentase Retribusi terhadap } \\
\text { Penerimaan Daerah }\end{array}$ & $2,9 \%$ & $3,1 \%$ & $3,2 \%$ \\
$\begin{array}{l}\text { Prosentase Retribusi terhadap } \\
\text { PAD }\end{array}$ & $41,8 \%$ & $43,0 \%$ & $31,1 \%$ \\
\hline
\end{tabular}

Grafik 9

Perbandingan Penerimaan Retribusi Daerah terhadap Pendapatan Daerah Kota Madiun Tahun Anggaran 2007, 2008, 2009

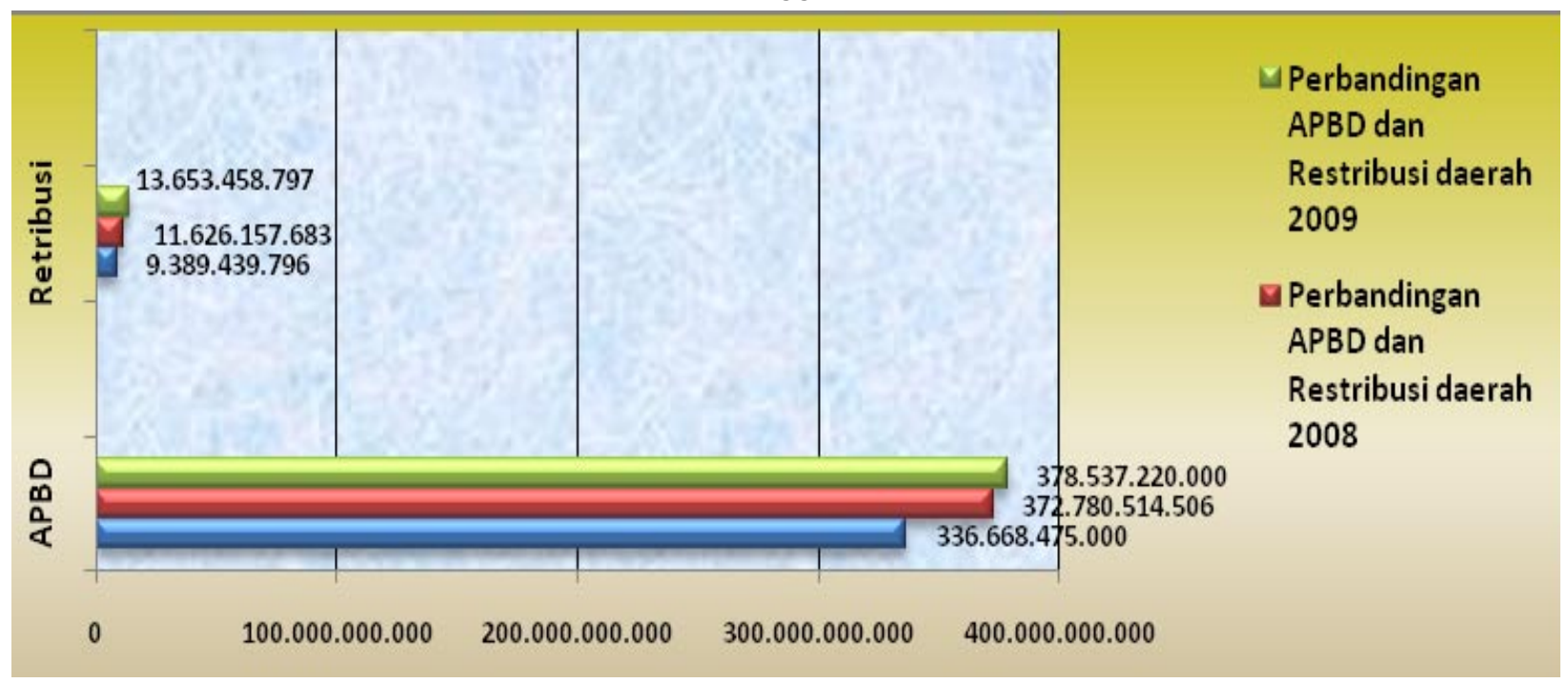

Magersari. Pertumbuhan perekonomian banyak didukung oleh kegiatan barang dan jasa yang terfasilitasi dalam perkembang Kota. Oleh sebab itu, Kota Mojokerto disebut juga kota UMKM, dimana sektor ini bertumbuh sangat pesat dengan berbagai jenis produksi. Kegiatan yang sangat besar adalah UMKM di bidang kerajinan Tas dan Aalas Kaki. Perkembangan 3 tahun terakhir posisi PAD terhadap APBD mengalami penurunan, meskipun besaran perolehan PADA terus meningkat. Dalam FGD yang dilakukan, diperoleh keterangan, bahwa peningkatan APBD di Kota Mojokerto banyak didukung oleh aliran DAU dan DAK. Namun perlu dicermati, bahwa kenaikan DAK tersebut juga karena Kota Mojokerto melakukan alokasi dana partisipasi dalam berbagai kegiatan pusat di daerah.

\section{Pertumbuhan Pajak Daerah}

Sebagai Kota yang berpenduduk sidikit, maka Mojokerto agak sulit untuk mengembangkan pendapatan dari sektor pajak. Wilayahnya yang sempit juga menjadi kendala untuk memperbesar peluang di bidang pajak daerah. Berdasarkan hasil diskusi yang dilakukan, diperoleh keterangan, bahwa tiga besar perolehan pajak diambil dari: Pajak Penerangan Jalan, Pajak Reklame, dan Pajak Hiburan. Dari tabel 11 berikut, dapat dibaca terjadinya penerimaan yang tidak terlalu besar dibandingkan dengan PAD dan APBD. Prosentase yang demikian kecil, membuktikan bahwa Kota Mojokerto tidak bisa mengandalkan pendapatannya dari sektor pajak. Oleh sebab itu sudah tepat jika terobosan meningkatkan APBD dilakukan dengan mencari tambahan DAK dan DAU 
Tabel 10

Prosentase Penerimaan PAD terhadap Pendapatan Daerah

Kota Mojokerto Tahun Anggaran 2007, 2008, 2009

\begin{tabular}{lccc}
\hline & Tahun 2007 & Tahun 2008 & Tahun 2009 \\
\hline Pendapatan Daerah & $312.177 .418 .056,82$ & $333.374 .591 .014,18$ & $358.964 .796 .758,45$ \\
PAD & $26.061 .952 .699,82$ & $26.276 .475 .864,33$ & $28.154 .863 .948,45$ \\
Prosentase & $8,3 \%$ & $7,9 \%$ & $7,8 \%$ \\
\hline
\end{tabular}

Grafik 10

Perbandingan Penerimaan PAD terhadap Pendapatan Daerah

Kota Mojokerto Tahun Anggaran 2007, 2008, 2009

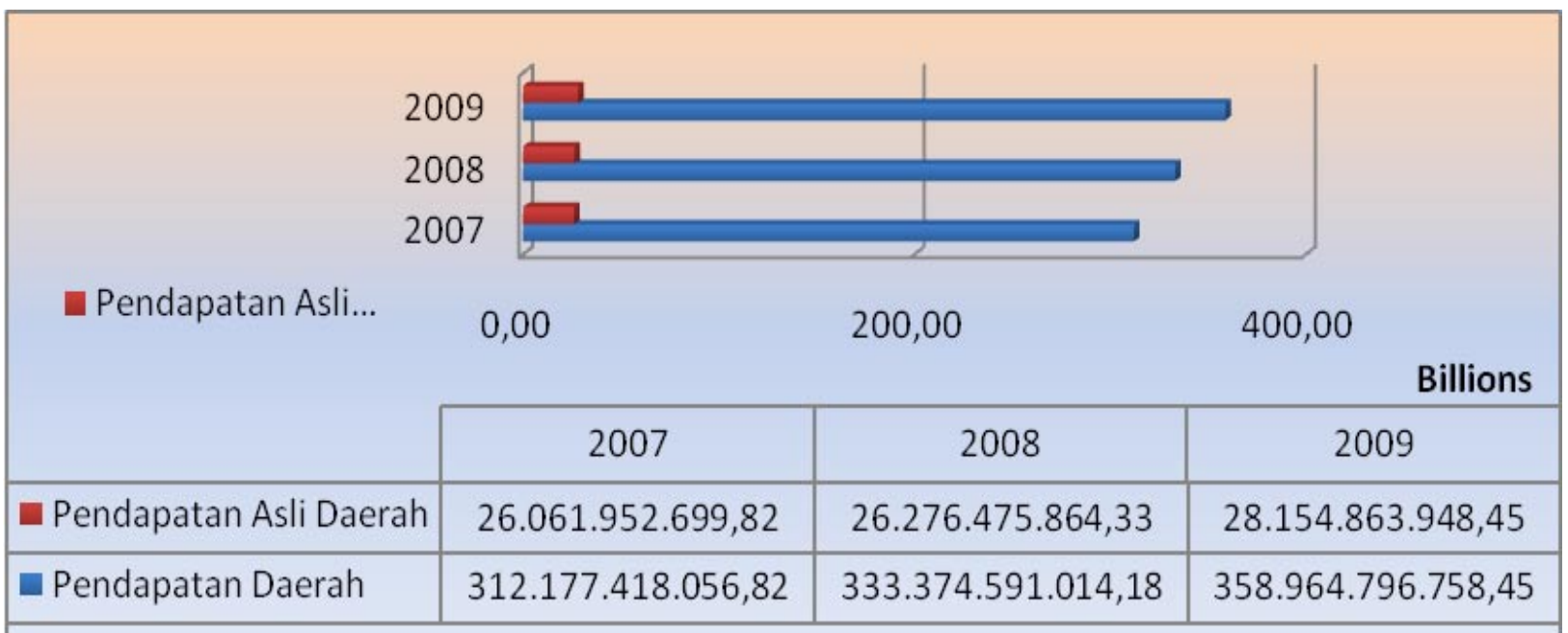

\section{Pertumbuhan Retribusi Daerah}

Dalam proses pemungutan retribusi, kota Mojokertomampumengoptimalkan penghasilannya, yang hal ini berimplikasi terhadap besaran prosentasi retribusi terhadap PAD dan APBD. Dari jenis-jenis retribusi yang dipungut, terdapat tiga besar, yaitu: retribusi Pelayanan Kesehatan, retribusi Parkir di Tepi Jalan Umum, dan Retribusi Pelayanan Pasar. Sementara itu, sumber pendapatan sektor retribusi yang kurang potensiil adalah: Retribusi Izin Trayek, Retribusi Jasa Penjualan Produk Usaha Daerah, dan Retribusi Pasar Grosir/Pertokoan.

Terhadap perolehan Retribusi yang tertinggi, jelas adalah Pelayanan Kesehatan. Dalam FGD diperoleh penjelasan, bahwa di Kota Mojokerto terdapat 3 rumah sakit tipe B, dan berbagai jenis Rumah Sakit Bersalin. Artinya bahwa Kota Mojokerto bisa menjadi kota rujukan bagi warga yang ada di sekitarnya, khususnya di Kabupaten Mojokerto dalam mencari jasa kesehatan.

\section{Pertumbuhan PAD terhadap Pendapatan Provinsi Jawa Timur}

Provinsi Jawa Timur adalah sebuah wilayah pemerintahan provinsi yang terdiri atas 38 kabupaten kota, sehingga dari unsur pemerintahannya, masuk dalam kategori terbesar. Penyelenggaraan pemerintahan di Jawa Timur bergerak pada upaya mencapai keberhasilan pembangunan daerah tersebut Gubernur Jawa Timur yang telah ditetapkan dalam Peraturan Gubernur Jawa Timur No. 38 Tahun 2009 tentang Rencana Pembangunan Jangka Menengah Daerah (RPJMD) Provinsi Jawa Timur Tahun 2009 - 2014, yang merupakan suatu perencanaan strategis, bahwa sumber daya dan dana daerah diarahkan untuk menangani isu dan permasalahan prioritas yang telah dituangkan dalam Program Pembangunan Jawa Timur tahun 2009 - 2014.

Berbagai prioritas pembangunan di Jawa Timur, memerlukan dukungan pendanaan yang sebagian 
Tabel 11

Prosentase Penerimaan Pajak Daerah dan Pendapatan Daerah Kota Mojokerto Tahun Anggaran 2007, 2008, 2009

\begin{tabular}{lccc}
\hline & Tahun 2007 & Tahun 2008 & Tahun 2009 \\
\hline PAD & $26.061 .952 .699,82$ & $26.276 .475 .864,33$ & $28.154 .863 .948,45$ \\
Penerimaan Pajak Daerah & $4.989 .660 .287,75$ & $5.835 .399 .446,31$ & $6.419 .093 .230,30$ \\
Prosentase terhadap Pendapatan & $1,7 \%$ & $1,7 \%$ & $1,8 \%$ \\
Daerah & & & $22,2 \%$ \\
Prosentase terhadap PAD & $19,1 \%$ & 22,8 \\
\hline
\end{tabular}

Grafik 11

Perbandingan Penerimaan Pajak Daerah terhadap PAD dan Pendapatan Daerah Kota Mojokerto Tahun Anggaran 2007, 2008, 2009

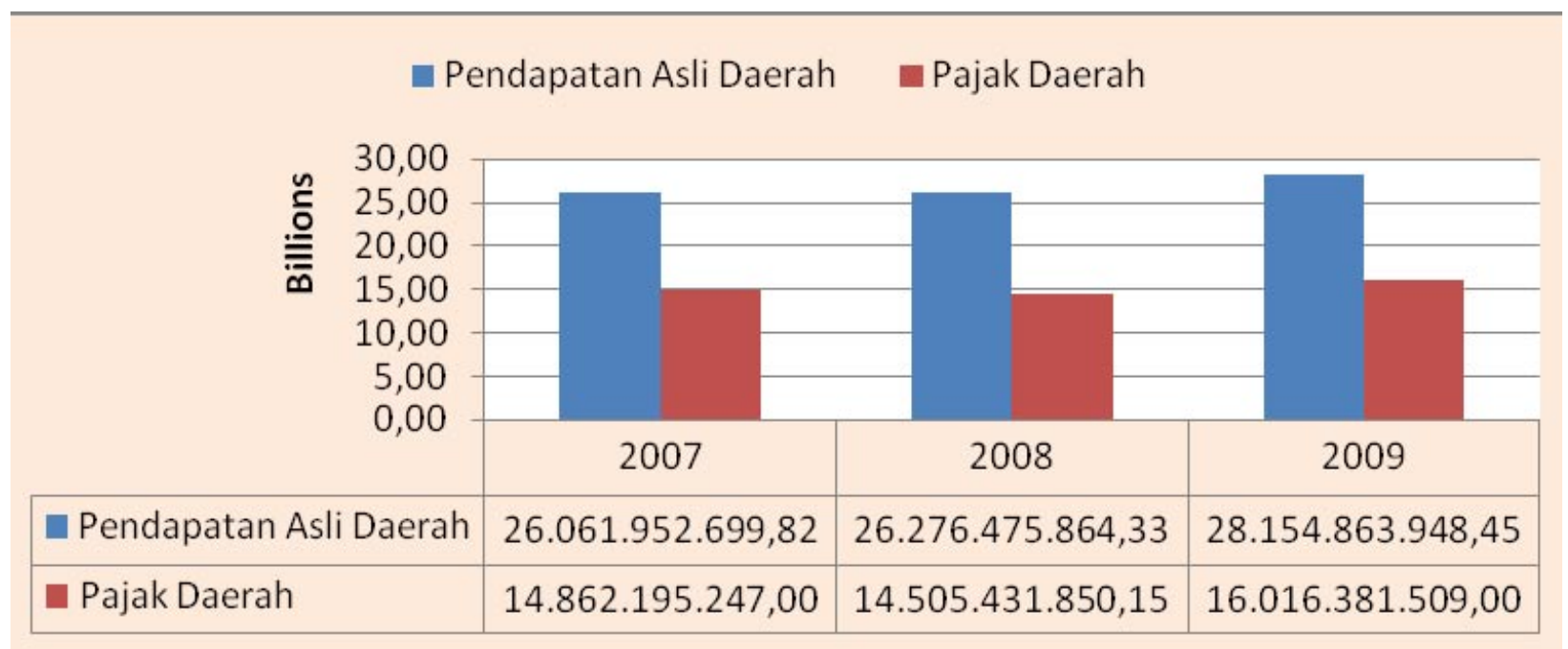

besar harus diperoleh dari PAD. Oleh sebab itu, berbagai upaya dilakukan untuk mencapai hal tersebut, khususnya perbaikan pelayanan publik dengan pembentukan unit Pelayanan Perizinan Terpadu (P2T). Hal itu dimaksudkan untuk memberi kemudahan bagi investor masuk ke Jawa Timur, dan pada akhirnya mampu menggerakan roda perekonamian secara makro.

Pertumbuhan perolehan PAD di Jawa Timur sangat memuaskan jika hal itu dibandingkan dengan APBD. Jawa Timur sudah sangat mampu membiayai kegiatan pemerintahan dan kebutuhan pembangunannya rata-rata $70 \%$. Hal ini berarti, tatakelola pemerintahan di Jawa Timur menawarkan kemandirian yang besar dalam hal membiayai diri sendiri. Penurunan pada tahun 2009 bukan karena potensinya yang hilang tetapi lebih disebabkan karena penurunan target di RAPBD 2009 yang ditetapkan pada tahun 2008 oleh DPRD Transisisi berikut Gubernurnya yang transisi. Meskipun demikian tetap hal itu harus dipandanag sebagai penurunan dan tetap harus ditingkatkan.

Dalam kegiatan pembangunan di tahun 20092010 sudah mulai nampak arah dan sasaran yang hendak dicapai dalam pembangunan Jawa Timur. Seperti terurai dalam rencana strategis RPJMD Jatim, antara lain: Pertama, program pengentasan kemiskinan, yaitu memenuhi hak-hak dasar yang meliputi kebutuhan pangan, kesehatan, pendidikan, pekerjaan dan berusaha, perumahan dan sanitasi, air bersih, pertanahan, sumber daya alam dan lingkungan hidup, rasa aman dari perlakuan atau ancaman tindak kekerasan serta hak berpartisipasi dalam kehidupan sosial politik. Dan salah satu instrumen untuk mempercepat mengurangi angka kemiskinan adalah mengoptimalkan program corporate social responsability (CSR); Kedua, Program menurunkan angka pengangguran, sebagai akibat dari dampak krisis keuangan global yang terjadi pada tahun 2008 yang berdampak pada pemutusan hubungan kerja (PHK). Adapun upaya-upaya yang perlu dilakukan adalah misalnya penanganan perluasan lapangan 
Tabel 12

Prosentase Retribusi terhadap PAD dan Pendapatan Daerah Kota Mojokerto Tahun Anggaran 2007, 2008, 2009

\begin{tabular}{lccc}
\hline & Tahun 2007 & Tahun 2008 & Tahun 2009 \\
\hline Penerimaan PAD & $26.061 .952 .699,82$ & $26.276 .475 .864,33$ & $28.154 .863 .948,45$ \\
Penerimaan Retribusi & $14.862 .195 .247,00$ & $14.505 .431 .850,15$ & $16.016 .380 .509,00$ \\
$\begin{array}{l}\text { Daerah } \\
\text { Prosentase Retribusi }\end{array}$ & $4,7 \%$ & $4,6 \%$ & $4,1 \%$ \\
$\begin{array}{l}\text { terhadap Pendapatan } \\
\text { Daerah }\end{array}$ & & & \\
$\begin{array}{l}\text { Prosentase Retribusi } \\
\text { terhadap PAD }\end{array}$ & $57,0 \%$ & $55,2 \%$ & $56,9 \%$ \\
\hline
\end{tabular}

Grafik 12

Perbandingan Penerimaan Retribusi terhadap PAD dan Pendapatan Daerah Kota Mojokerto Tahun Anggaran 2007, 2008, 2009

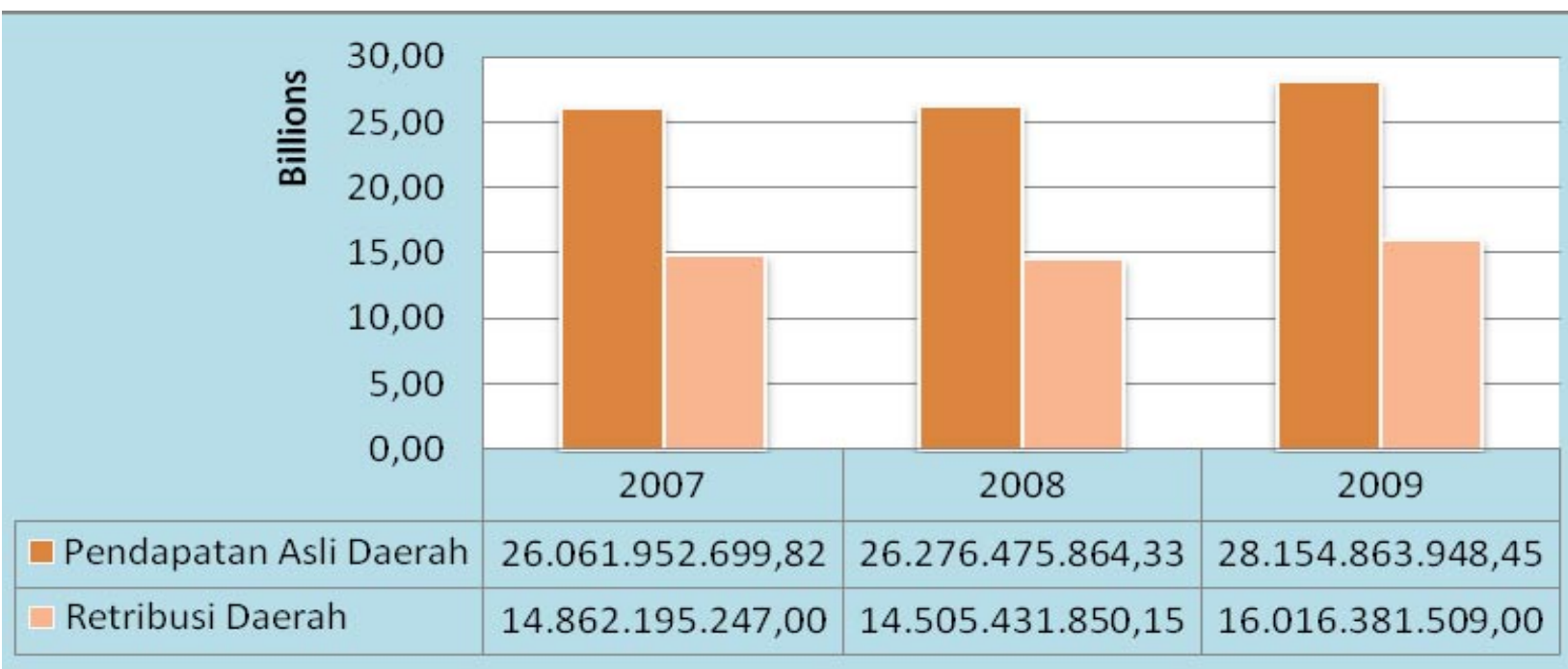

kerja dengan memfungsikan balai latihan kerja (BLK); Ketiga, Program meningkatkan pertumbuhan ekonomi, upaya yang perlu dilakukan misalnya adalah menciptakan iklim investasi yang kondusif dengan konsep pelayanan perizinan terpadu (P2T) dan inovasi teknologi tepat guna (TTG) di sektor pertanian; Keempat, Program meningkatkan indeks pembangunan manusia (IPM) sebagai ukuran keberhasilan pembangunan suatu daerah, upaya yang perlu dilakukan adalah senantiasa mengupayakan peningkatan IPM melalui aksesibilitas pendidikan, kesehatan, dan daya beli masyarakat. Berdasar berbagai sasaran pokok program dalam renstra RPJMD Jatim 20092014, maka diperlukan dukungan dana yang cukup. Perolehan PAD Jatim seperti terurai di Tabel 13, sangat memungkinkan bagi Pemerintah Provinsi Jawa Timur untuk mencapai targer pembangunan dimaksud.

\section{Pertumbuhan Pajak Propinsi Jawa Timur}

Perkembangan jenis pajak Provinsi mengalami perkembangan dari waktu kewaktu baik dari segi jenis dan besaran tarif yang boleh dipungut. Tentu terdapat alasan-alasan yang sangat bisa diterima seperti: Pertama, perubahan Undang-undang Nomor 5 Tahun 1974 digantikan dengan UU Nomor 22 Tahun 1999 yang berimplikasi pada perubahan jenis Pajak Provinsi. Kedua, perubahan kembali Undang-Undang Nomor 22 Tahun 1999 menjadi Undang-Undang Nomor 32 Tahun 2004 pun membawa konskwensi tata kelola pendapatan daerah harus diubah.

Seperti yang terlihat dalam perbandiangan berikut antara Undang-Undang Nomor 18 Tahun 1997 dengan Undang-Undang Nomor 34 Tahun 2000 yang menjadi UU perubahan, sebagai berikut:

Dalam pengelolaan pemungutan Pajak di Jawa Timur, diberlakukan jenis perda pajak, yaitu: 
Tabel 13

Prosentase Penerimaan PAD terhadap Pendapatan Daerah Provinsi Jawa Timur Tahun Anggaran 2007, 2008, 2009

\begin{tabular}{lccc}
\hline & Tahun 2007 & Tahun 2008 & Tahun 2009 \\
\hline APBD & 5.940 .048 .022 .274 & 7.075 .105 .412 .658 & 7.827 .694 .815 .533 \\
Penerimaan PAD & 4.164 .250 .659 .987 & 5.212 .319 .315 .953 & 5.708 .040 .337 .082 \\
$\begin{array}{l}\text { Prosentase PAD } \\
\text { terhadap APBD }\end{array}$ & $70,1 \%$ & $73,7 \%$ & $72,9 \%$ \\
\hline
\end{tabular}

Grafik 13

Perbandingan Penerimaan PAD terhadap Pendapatan Daerah Provinsi Jawa Timur Tahun Anggaran 2007, 2008, 2009

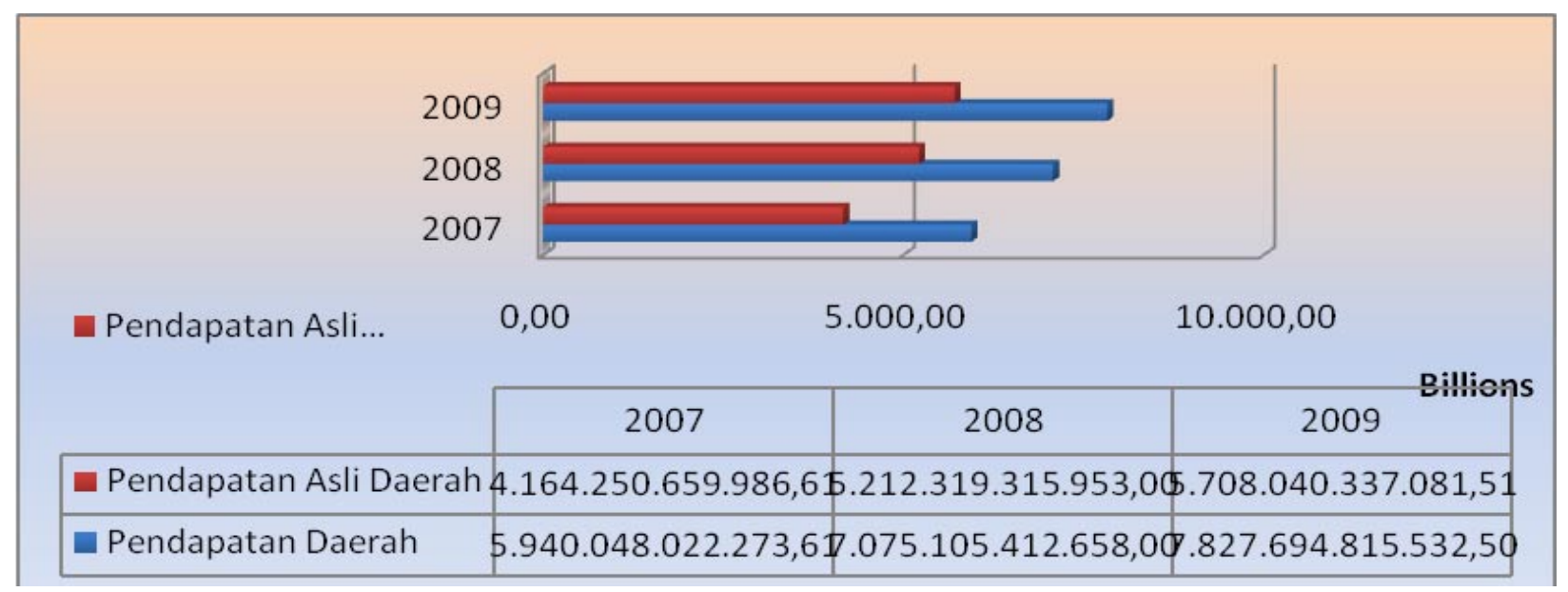

Tabel 14

Perbandingan Jenis Pajak Provinsi antara UU 18/1997 dengan UU 34/2000

\begin{tabular}{|c|c|}
\hline $\begin{array}{c}\text { UU 18/1997 } \\
\text { Pasal } 2\end{array}$ & UU 34/2000 \\
\hline $\begin{array}{l}\text { Jenis Pajak Daerah Tingkat I terdiri dari: } \\
\text { a. Pajak Kendaraan Bermotor } \\
\text { b. Bea Balik Nama Kendaraan Bermotor } \\
\text { c. Pajak Bahan Bakar Kendaraan Bermotor } \\
\\
\text { Tarif Pajak ditetapkan paling tinggi sebesar: } \\
\text { a. Pajak Kendaraan Bermotor 5\% (lima persen) } \\
\text { b. Bea Balik Nama Kendaraan Bermotor 10\% (sepuluh } \\
\text { persen) } \\
\text { c. Pajak Bahan Bakar Kendaraan Bermotor 5\% (lima } \\
\text { persen) }\end{array}$ & $\begin{array}{l}\text { Jenis Pajak Propinsi terdiri dari: } \\
\text { a. Pajak Kendaraan Bermotor dan Kendaraan di atas Air; } \\
\text { b. Bea Balik Nama Kendaraan Bermotor dan Kendaraan di atas } \\
\text { Air; } \\
\text { c. Pajak Bahan Bakar Kendaraan Bermotor; } \\
\text { d. Pajak Pengambilan dan Pemanfaatan Air Bawah Tanah dan Air } \\
\text { Permukaan } \\
\text { Tarif Pajak ditetapkan paling tinggi sebesar: } \\
\text { a. Pajak Kendaraan Bermotor dan Kendaraan di atas Air 5\% (lima } \\
\text { persen) } \\
\text { b. Bea Balik Nama Kendaraan Bermotor dan Kendaraan di atas } \\
\text { Air 10\% (sepuluh persen) } \\
\text { c. Pajak Bahan Bakar Kendaraan Bermotor 5\% (lima persen) } \\
\text { d. Pajak Pengambilan dan Pemanfaatan Air Bawah Tanah dan Air } \\
\text { Permukaan 20\% (dua puluh persen) }\end{array}$ \\
\hline
\end{tabular}

Pertama, Pajak Kendaraan Bermotor (PKB) Kedua, Pajak Balik Nama Kendaraan Bermotor (PBNKB) Ketiga, Pajak Bahan Bakar Kendaraan Bermotor (PBBKB) Keempat, Pajak Air Permukaan (PAP), dan Kelima, Pajak Air Bawah Tanah (PABT).

Besaran pungutan atas Pajak daerah tersebut terdiskripsi pada tabel 15 , perkembangan jumlah penerimaannya yang semakin meningkat, meskipun secara prosentase mengalami fluktuasi jika dibandingkan dengan APBD atau PAD. Dalam Tabel tersebut nampak kekuatan Pajak Daerah yang siap mendukung kemampuan daerah dalam 
Tabel 15

Presentase Penerimaan Pajak Daerah terhadap PAD dan Pendapatan Daerah Provinsi Jawa Timur, Tahun Anggaran 2007, 2008, 2009

\begin{tabular}{lccc}
\hline & Tahun 2007 & Tahun 2008 & Tahun 2009 \\
\hline Penerimaan & 5.940 .048 .022 .274 & 7.075 .105 .412 .658 & 7.827 .694 .815 .533 \\
PAD & 4.164 .250 .659 .987 & 5.212 .319 .315 .953 & 5.708 .040 .337 .082 \\
Pajak Daerah & 3.574 .886 .241 .780 & 4.481 .791 .543 .639 & 4.891 .816 .302 .939 \\
Prosentase Pajak & & & $65.5 \%$ \\
$\begin{array}{l}\text { Daerah terhadap } \\
\text { Pendapatan Daerah }\end{array}$ & $69,7 \%$ & $63,4 \%$ & \\
\hline
\end{tabular}

Grafik 14

Persentase Penerimaan Pajak Daerah terhadap PAD dan Pendapatan Daerah Provinsi Jawa Timur, Tahun Anggaran 2007, 2008, 2009

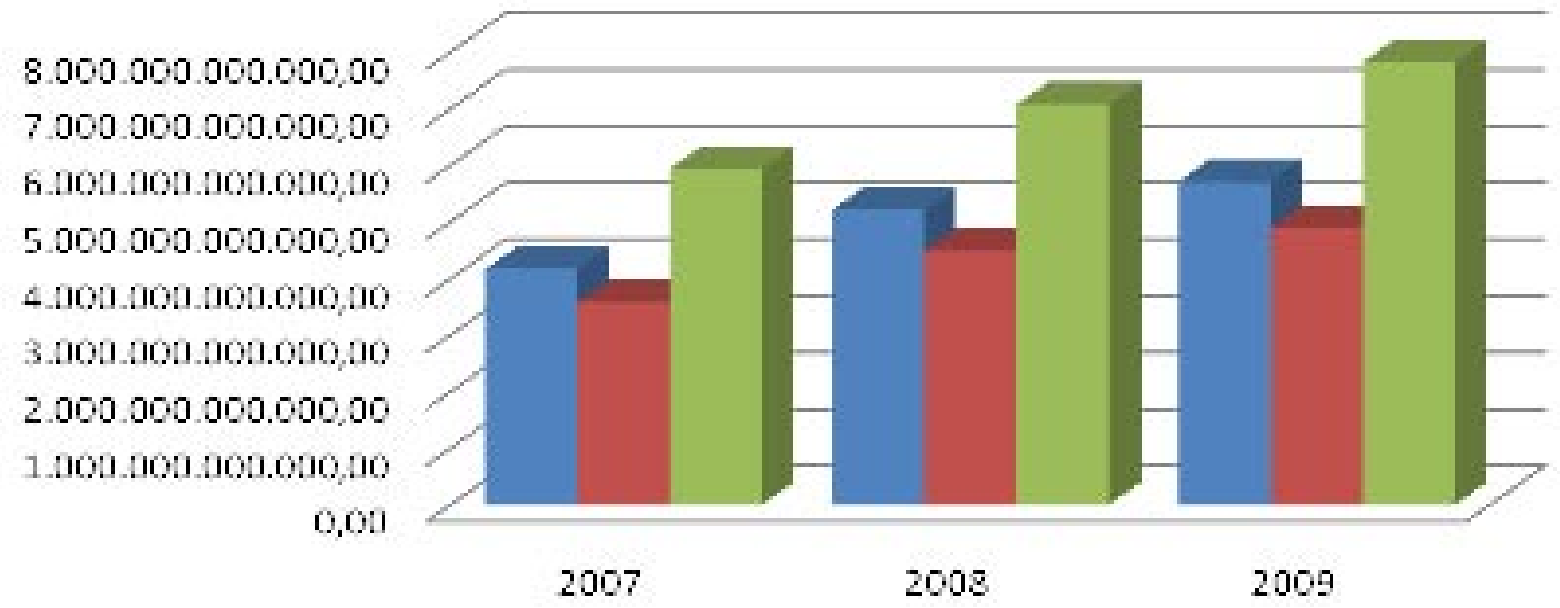

Pendapatan Asli Derah a PajakDaerah a Pendapatan Derah

Tabel 16

Presentase Penerimaan Retribusi terhadap PAD dan Pendapatan Daerah

Provinsi Jawa Timur, Tahun Anggaran 2007, 2008, 2009

\begin{tabular}{lccc}
\hline & Tahun 2007 & Tahun 2008 & Tahun 2009 \\
\hline APBD & 5.940 .048 .022 .274 & 7.075 .105 .412 .658 & 7.827 .694 .815 .533 \\
Penerimaan PAD & 4.164 .250 .659 .987 & 5.212 .323 .367 .729 & 5.708 .040 .337 .082 \\
Penerimaan Retribusi & 261.100 .680 .458 & 309.323 .367 .729 & 75.609 .005 .674 \\
$\begin{array}{l}\text { Prosentase Retribusi } \\
\text { Daerah terhadap }\end{array}$ & $0,15 \%$ & $0,44 \%$ & $0,09 \%$ \\
$\begin{array}{l}\text { Pendapatan Daera } \\
\text { Prosentase Retribusi }\end{array}$ & $6,3 \%$ & $5,9 \%$ & $1,3 \%$ \\
Daerah terhadap PAD & & & \\
\hline
\end{tabular}


Grafik 15

Prosentase Penerimaan Retribusi Daerah terhadap PAD dan Pendapatan Daerah Provinsi Jawa Timur, Tahun Anggaran 2007, 2008, 2009

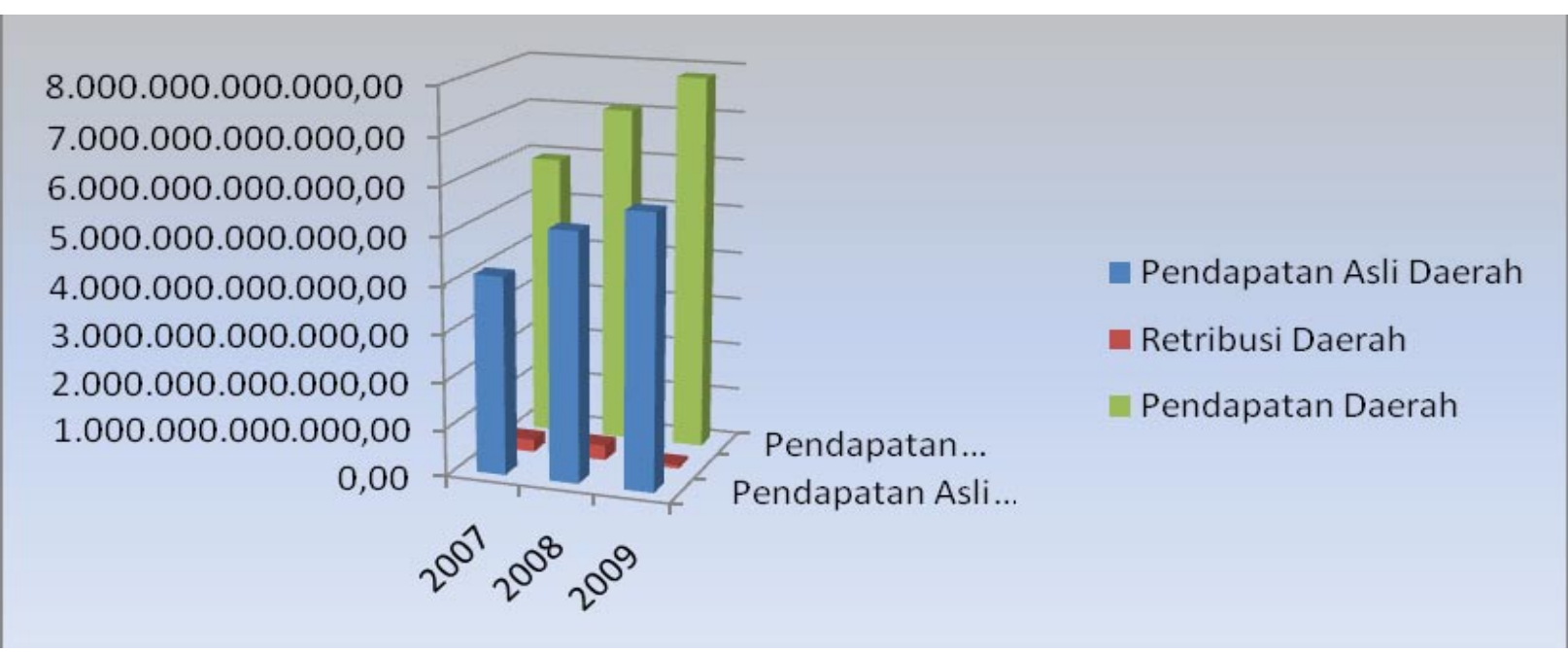

memenuhi APBD. Jadi, Jawa Timur dapat dikatakan mempunyai kemandirian dalam melakukan pembiayaan urusan daerah (rumah tangga sendiri).

\section{Pertumbuhan Retribusi Propinsi Jawa Timur}

Berdasarkan keterangan dari perangkat pemungut, diperoleh penjelasan urut-urutan obyek retribusi yang potensiil di Jawa Timur: Retribusi Pemakaian Kekayaan Daerah, Retribusi Izin Perpanjangan Kerja, dan Retribusi Rumah Potong Hewan. Sementara retribusi yang kurang potensiil adalah: Retribusi Izin Trayek, Retribusi Pengelolaan TAHURA, dan Retribusi Pengujian Kapal Ikan.

\section{PENUTUP}

Berdasarkan uraian dalam bagian pembahasan dapat diambil kesimpulan bahwa Posisi Pajak dan Retribusi Daerah sangat strategis bagi penyelenggaraan pemerintahan daerah (baik kabupaten/kota maupun propinsi) khususnya sebagai indikator keberhasilan otonomi daerah dengan aspek kemampuan keuangan daerah untuk membiayai pelaksanaan urusan wajibnya.

Berdasarkan kesimpulan sebagaimana telah diuraikan, maka dapat disampaikan saran-saran bahwa dalam upaya meningkatkan pendapat daerah dari sektor Pajak dan Retribusi Daerah, maka penyesuaian Perda tentang Pajak dan Retribusi Daerah harus memperhatikan tenggat waktu yang telah ditetapkan dalam Undang-Undang Nomor 28 Tahun 2009 agar dukungan keuangan dari hasil pemungutan Pajak dan Retribusi Daerah dapat dipenuhi.

\section{DAFTAR PUSTAKA}

Atre, B.R., 2001, Legislative Drafting: Principles and Techniques, Universal Law Publishing Co.

Bandung Institute of Government Studies (BIGS), 2002, Merancang Kebijakan Perizinan yang Pro Pasar dan Sensitif Kepentingan Publik, in Cooperation with Patnership for Economic Growth, Jakarta.

Basah, Sjachran, 1996, Sistem Perizinan sebagai Instrumen Pengendalian Lingkungan Dalam Butir-Butir Gagasan tentang Penyelenggaraan Hukum dan Pemerintahan yang Layak, Bandung: Citra Aditya Bakti.

Berge ten B.J.B.M. dan Spelt, N.M., 1993, Pengantar Hukum Perizinan, Cetakan I, Surabaya: Yuridika.

Budiman Arief, 1996, Teori Pembangunan Dunia Ketiga, Jakarta: Gramedia Pustaka Utama.

David Ray, 2003, Desentralisasi, Reformasi Peraturan dan Iklim Usaha, Patnership for Economic Growth (PEG), Departemen Perindustrian dan Perdagangan, Jakarta.

ELIPS, (2001), Penyusunan Rancangan UndangUndang dalam Perubahan Masyarakat yang Demokratis, Business Advisory Indonesia University of San Francisco Scholl of Law Indonesia Program.

Eny Rahmawati, "Pelaksanaan Retribusi Pasar dalam Peningkatan Pendapatan Asli Daerah (Studi pada Kantor Dispenda Kabupaten Lamongan)".

Fitri Junitasari, "Analisis Potensi Pendapatan Asli Daerah Kabupaten Lamongan”, http://digilib. 
umm.ac.id/gdl.php?mod=browse\&op=read\& id=jiptummpp-gdl-s1-2009-fitrijunit-15713\& PHPSESSID $=42 \mathrm{~d} 6 \mathrm{ee} 65 \mathrm{~b} 827 \mathrm{a} 38 \mathrm{f} 44956092 \mathrm{~d} 28$ ba985.

Forum Komunikasi LSM APIK, 1995, Landasan Aksi dan Deklarasi Beizing, Jakarta: APIK.

Hadjon, P. M., 1990, Perlindungan Hukum Bagi Rakyat di Indonesia, Surabaya: Bina Ilmu. 1994, Fungsi Normatif Hukum Administrasi dalam Mewujudkan Pemerintahan yang Bersih, Pidato peresmian penerimaan jabatan Guru Besar dalam Ilmu Hukum, Surabaya: Universitas Airlangga.

1995, Aspek-aspek Hukum Administrasi dari Keputusan Tata Usaha Negara (KTUN), Makalah, Bandung.

1995, Pengantar Hukum Administrasi di Indonesia, Yogyakarta: Gajah Mada University Press.

Hartono Sunaryati, 1994, Penelitian Hukum di Indonesia pada Akhir Abad ke-20, Bandung, Alumni.

Indra J. Piliang, dkk. (Editor), Faisal H. Basri Cetakan I Nopember, 2005, Otonomi Daerah Evaluasi \& Proyeksi., Divisi Kajian Demokrasi Lokal, Jakarta: Yayasan Harkat Bangsa.

Koentjoro Purbopranoto, 1978, Beberapa Catatan tentang Hukum Tata Pemerintahan dan Peradilan Administrasi Negara, Bandung: Alumni.

Madekhan Ali, "Catatan Pinggir Untuk LKPJ Bupati Lamongan," Budget Info, Daulat atas Anggaran, http://www.budgetinfo.com/ index.php?option=com_ content\& view $=$ article $\&$ id $=\quad 353 \% 3$ Acata $\quad$ tanpinggir-untuk-lkpj-bupati-lamongan\&catid $=48 \% 3$ Alocal-budget-sektor-lain\&Itemid $=259$ \&lang $=$ in.

Mario Hally Hadiwijaya, 2001-2006, "Peranan Sektor Pariwisata terhadap Penyerapan Tenaga Kerja dan Pendapatan Asli Daerah Kabupaten Lamongan http:// digilib.unej.ac.id/gdl42/gdl. php? mod=browse \&op=read\&id=gdlhub-gdlmariohally-2368.

Mohammad, Anwar, et.al., 2006-2010, "Evaluasi RPJMD Kabupaten Lamongan-Jatim".

Sobana, 1996, Adaptasi Pelayanan Izin Investasi terhadap Perubahan Lingkungan dalam ButirButir Gagasan tentang Penyelenggaraan Hukum dan Pemerintahan yang Layak, Bandung: Citra Aditya Bakti.
Sadu Wasisto, 2003, Edisi Revisi, Kapita Selekta Manajemen Pemerintahan Daerah, Bandung: CV. Fokus Media.

Soemitro, Rochmad, 1988, Pajakdan Pembangunan, Bandung: Eresco.

Soekarwo, dkk., 2006, Pelayanan Publik, dari Dominasi ke Partisipai, Surabaya: Airlangga University Press.

Undang-undang Nomor 10 Tahun 2004 tentang Pembentukan Peraturan Perundang-undangan.

Undang-undang Nomor 32 Tahun 2004 tentang Pemerintahan Daerah.

Undang-undang Nomor 33 Tahun 2004 tentang Perimbangan Keuangan Antara Pusat dan Pemerintah daerah.

UU Nomor 14 Tahun 2008 tentang Keterbukaan Informasi Publik.

UU Nomor 25 Tahun 2009 tentang Pelayanan Publik.

Undang-undang Nomor 28 Tahun 2009 tentang Pajak dan Retribusi Daerah.

Peraturan Pemerinatah Nomor 19 Tahun 1997 tentang Pajak Daerah

Peraturan Pemerintah Nomor 20 Tahun 1997 tentang Retribusi Daerah.

Data Rekapitulasi APBD Kabupaten Lamongan Tahun Anggaran 2007, 2008 dan 2009.

Data Rekapitulasi APBD Kabupaten Pasuruan Tahun Anggaran 2007, 2008 dan 2009.

Data Rekapitulasi APBD Kota Madiun Tahun Anggaran, 2007, 2008 dan 2009.

Data Rekapitulasi APBD Kota Mojokerto Tahun Anggaran 2007.2008, dan 2009.

Data Rekapitulasi APBD Provinsi Jawa Timur Tahun Anggaran 2007, 2008 dan 2009.

Data kondisi geografis dan demografis dikutip dari Situs (website) resmi Pemerintah Daerah Kabupaten Lamongan, Pemutakhiran Terakhir ( Friday, 13 June 2008), diakses melalui http:// www. lamongan.go.id/index.php?option=com content\&task $=$ view\&id $=441 \&$ Itemid $=439$.

Data kondisi geografis dan demografis dikutip dari Situs (website) resmi Pemerintah Daerah Kabupaten Pasuruan, http://www. pasuruan kab.go.id/perda.php?cID=3\&action=list.

Rekapitulasi Target dan Realisasi Penerimaan Pendapatan Asli Daerah Kabupaten/Kota Seluruh Jawa Timur Sektor Hasil Pajak Daerah, BPS Provinsi Jawa Timur, http://jatim.bps.go.id/ wp-content/ uploads/images/PAD1.pdf.

Rekapitulasi Target dan Realisasi Penerimaan 
Pendapatan Asli Daerah Kabupaten/Kota Seluruh Jawa Timur Sektor Hasil Retribusi Daerah, http://jatim.bps.go.id/wp-content/ uploads/images/ PAD2.pdf.

"Paparan Hasil Monitoring Otonomi Daerah di Jatim 2007," Selasa, 15 Mei 2007, http://webcache. googleusercontent.com/search?q=cache: KOXibFhy5hgJ:www.adkasi.org/upload/File/ Paparan\%2520Monitoring\%2520Pelaksanaan\% 2520Otonomi\%2520Daerah,\%2520Jawa\%2520 Pos.doc+analisis + data + pajak + daerah + kabupate $\mathrm{n}+$ pasuruan \&cd $=35 \& \mathrm{hl}=\mathrm{id} \& \mathrm{ct}=\mathrm{clnk} \& \mathrm{gl}=\mathrm{id}$.

"Pandangan Umum Nota Keuangan Pemda
Pasuruan", Fraksi Partai Kebangkitan Bangsa, http://www.bungjack.co.cc/2009/12/pandanganumum-nota-keuangan-pemda. html.

Profil Kabupaten/Kota, Kota Mojokerto, http: //ciptakarya.pu.go.id/rofil/profil/barat/jatim/ mojokerto.pdf.

RPJMD Kota Madiun yang telah disahkan menjadi Perda No. 19 Tahun 2009, http://bappeda. madiunkota.info/wp-content/ uploads/2010/01/ rpjm.pdf.

RPJPD Kota Madiun 2005-2025, http://bappeda. madiunkota.info/wp-content/uploads 2010/06/ perda-rpjp.pdf. 